J. Dairy Sci. 98:7865-7885

http://dx.doi.org/10.3168/jds.2015-9866

(C) 2015, THE AUTHORS. Published by FASS and Elsevier Inc. on behalf

of the American Dairy Science Association ${ }^{\circledR}$. This is an open access article under

the CC BY-NC-ND license (http://creativecommons.org/licenses/by-nc-nd/3.0/).

\title{
Association of bedding types with management practices and indicators of milk quality on larger Wisconsin dairy farms
}

\author{
R. F. Rowbotham ${ }^{*} \dagger^{1}$ and P. L. Ruegg* \\ *Department of Dairy Science, University of Wisconsin, Madison 53706 \\ †Grande Cheese Company, Brownsville, WI 53006
}

\begin{abstract}
The objective of this study was to identify associations of bedding type and selected management practices with bulk milk quality and productivity of larger Wisconsin dairy farms. Dairy herds $(\mathrm{n}=325)$ producing $\geq 11,340 \mathrm{~kg}$ of milk daily were surveyed during a single farm visit. Monthly bulk milk SCC and total bacteria counts were obtained from milk buyers for 255 farms for a 2-yr period. Of farms with the same type of bedding in all pens during the study period, most used inorganic bedding (IB), followed by organic nonmanure bedding $(\mathrm{OB})$ and manure products $(\mathrm{MB})$. Almost all bulk milk total bacterial counts were $<10,000 \mathrm{cfu} /$ $\mathrm{mL}$ and total bacterial count was not associated with bedding type. Bulk milk somatic cell score (BMSCS) was least for farms using IB, varied seasonally, and was greatest in the summer. The BMSCS was reduced when new bedding was added to stalls at intervals greater than $1 \mathrm{wk}$ and when teats were dried before attaching the milking unit. The BMSCS for farms using OB was reduced when bedding in the backs of stalls was removed and replaced regularly and when fewer cows with nonfunctioning mammary quarters were present. The BMSCS for farms using MB was reduced when the proportion of cows with milk discarded was less. The rolling herd average (RHA) of herds using IB was 761 and $1,153 \mathrm{~kg}$ greater than the RHA of herds using $\mathrm{OB}$ and $\mathrm{MB}$, respectively. The RHA was $353 \mathrm{~kg}$ greater on farms where farmers understood subclinical mastitis and $965 \mathrm{~kg}$ greater on farms milking 3 times daily. Each 1\% increase of cows with nonfunctioning mammary quarters was associated with a decrease of $57 \mathrm{~kg}$ of RHA. The BMSCS, proportions of cows with milk discarded and proportion of cows with nonfunctioning mammary quarters were least for herds using IB
\end{abstract}

Received May 26, 2015.

Accepted June 26, 2015.

${ }^{1}$ Corresponding author: rob.rowbotham@grande.com and were associated with increased productivity. Large Wisconsin dairy farms that used inorganic bedding had greater productivity and better milk quality compared with herds using other bedding types.

Key words: bedding, mastitis, milk quality, management

\section{INTRODUCTION}

Demand for dairy products is driven by consumer desire for inexpensive food that is safe, high quality, and produced using socially responsible management practices (Rollin, 2004; Fulwider et al., 2008; Sapp et al., 2009). Bulk milk somatic cell count (BMSCC) and total bacterial count (BMTBC) are international reference indicators of raw milk quality (Costello et al., 2003). Production of high quality milk from healthy animals is a requirement for market access (Europa, 2009; Wisconsin Administrative Code, 2013), and processors are increasingly demanding milk that meets international standards for these indicators.

Bulk milk SCC is associated with prevalence of IMI (Schukken et al., 2003) and is often used as a determinant for payment of premiums by milk purchasers (Rowbotham, 2000; Jayarao et al., 2004). Increased premiums for milk with low BMSCC directly increases milk price and gross farm revenue. Reduced prevalence of IMI (often measured as BMSCC) is associated with increased productivity and profitability and improved animal welfare (Ott and Novak, 2001; Schukken et al., 2003). Somatic cells migrate to the mammary gland in response to infection, so reducing the prevalence of IMI is crucial to reducing BMSCC (Deluyker et al., 1993; Schukken et al., 2003). Through adoption of modern milking practices, many farms have controlled transmission of contagious mastitis pathogens and have reduced the prevalence of intramammary infections caused by these organisms (Makovec and Ruegg, 2003). Currently in the United States, environmental mastitis pathogens account for the greatest proportion of IMI, whereas only 2 decades ago most IMI were caused by conta- 
gious pathogens (Lago et al., 2011; Pinzón-Sánchez and Ruegg, 2011; Oliveira et al., 2013).

Bacterial exposure at the teat end is a primary source of exposure to potential mastitis pathogens, and reducing this exposure is an important aspect of controlling environmental mastitis. Teats become contaminated with environmental bacteria through contact with bedding and other environmental risk factors (Rendos et al., 1975; Schreiner and Ruegg, 2003; Zdanowicz et al., 2004; DeVries et al., 2012). Teats may be in direct contact with bedding materials for 12 to $14 \mathrm{~h}$ per day, making bedding a primary reservoir for environmental pathogens (Tucker and Weary, 2004; Cook et al., 2005; Hogan and Smith, 2012). The number of bacteria on teat skin has been shown to represent the level of exposure to some mastitis pathogens (Zdanowicz et al., 2004), and increased exposure has been associated with increased rates of clinical mastitis (Hogan et al., 1989).

Bulk milk total bacterial count is a measure of the microbial content of milk, is associated with animal hygiene and milk quality, and is frequently used as a basis for determining milk quality premiums (Pantoja et al., 2009; Velthuis and van Asseldonk, 2011). Bacteria in raw milk can originate from IMI, contamination during milking, inadequate cleaning of milking equipment, or failure to properly cool and store milk (Reinemann et al., 1997).

For several decades the proportion of milk produced by large dairy farms in the United States has been increasing. Herds containing $\geq 200$ milk cows currently produce $75 \%$ of all milk and those containing $\geq 500$ cows produce $63 \%$ of US milk (USDA-NASS, 2014b). This segment of herds will continue to produce the majority of milk sold in the United States, so it is imperative that we understand the effect of housing and management decisions used on these larger farms. The objective of this study was to determine associations of bedding type and selected management practices with bulk milk quality and productivity of larger Wisconsin dairy farms.

\section{MATERIALS AND METHODS}

\section{Herd Recruitment and Inclusion Criteria}

A list of licensed dairy producers was purchased from the Wisconsin Department of Administration (2012). Farms on this list had been previously categorized by size from processor records or farm visits. Inclusion criteria required farms to be producing at least 11,340 $\mathrm{kg}$ of milk (1/2 of a milk tanker truck) daily and to be actively selling milk from May 1, 2010, to April 30, 2012. Between June 2012 and October 2013, researchers mailed postcards to potentially eligible farms $(\mathrm{n}=$
428), advising them that they would be soon be visited by a researcher. These farms were visited between June 26, 2012, and December 1, 2013, resulting in the identification of 387 eligible farms, after excluding farms not meeting inclusion criteria $(n=41)$. Survey administrators also excluded 27 farms after failing to make contact with farm owners after 3 or more visits. Thirty-five farmers refused to participate, resulting in participation of $325(84.0 \%)$ of eligible farms in the survey (Table 1).

\section{Data Collection}

Survey of Management Practices. Survey administrators $(\mathrm{n}=5)$ were trained as a group and practiced administering questionnaires during a 1-d training session. Following training, each survey administrator observed the administration of the questionnaires by the trainer (R.F.R.) on at least 2 farms followed by being observed on at least 2 farms by the trainer before administering questionnaires on their own. During the 18 mo when the survey was conducted, survey administrators met as a group monthly to discuss progress and to avoid procedural drift.

Five trained survey administrators (including the first author) administered a 60-question survey instrument (http://milkquality.wisc.edu/association-of-milk-quality-to-bedding/) including herd profile, inventory, and production (6 questions); bulk milk cooling and cleaning (8 questions); use of DHI, California Mastitis Test (CMT), and bacteriologic culturing of milk samples (6 questions); milking management and routine (17 questions); level of management expertise (5 questions); types and management of bedding (8 questions); and parlor design and management (10 questions). Most questions were close-ended, but some questions (such as those collecting information on brands and trade names of teat dips) were open-ended with responses categorized postsurvey.

Collection of Milk Quality Test Results. For each farm, survey administrators requested a release of bulk milk test results from milk buyers for the period from May 1, 2010, to April 30, 2012. Information obtained from processors included date of shipment, milk weight, BMSCC, and BMTBC. Bulk milk test results were delivered to the senior author (P.L.R.) who removed all potentially identifying information and merged the survey data with the bulk milk results. This blinding was used to avoid any potential conflict of interest due to the first author's employment within the dairy processing industry.

Bulk milk test results received for farms using the same bedding in all pens during the entire study (n $=230$ ) were used to analyze associations among indi- 
Table 1. Description of Wisconsin dairy herds enrolled and eligible for model entry

\begin{tabular}{|c|c|}
\hline Characteristic & $\begin{array}{c}\text { Farms } \\
(\mathrm{n})\end{array}$ \\
\hline Wisconsin licensed dairy herds in 2010 & 12,770 \\
\hline \multicolumn{2}{|l|}{ Excluded due to producing $<11,340 \mathrm{~kg}$ milk per day } \\
\hline Initial exclusions using processor records & 12,342 \\
\hline Exclusions based on personal interviews & 41 \\
\hline Potential study participants & 387 \\
\hline \multicolumn{2}{|l|}{ Excluded } \\
\hline Excluded, unable to contact farm owner & 27 \\
\hline Excluded, farmer declined participation & 35 \\
\hline Farms that were surveyed & 325 \\
\hline Used different bedding in different pens or over time & 39 \\
\hline Farms with the same bedding in all pens during the study period & 286 \\
\hline Inorganic bedding ${ }^{1}$ & 195 \\
\hline Organic nonmanure bedding ${ }^{2}$ & 62 \\
\hline Manure products for bedding ${ }^{3}$ & 29 \\
\hline \multicolumn{2}{|l|}{ Farms eligible for analysis of BMSCS by bedding type } \\
\hline Farms with the same bedding in all pens during the study & 286 \\
\hline Excluded, milk quality test results not received from processors & 56 \\
\hline Farms included in multivariate models & 230 \\
\hline \multicolumn{2}{|l|}{ Bedding used on enrolled farms included in analysis } \\
\hline Inorganic bedding ${ }^{4}$ & 156 \\
\hline Organic nonmanure bedding ${ }^{5}$ & 49 \\
\hline Manure products for bedding ${ }^{6}$ & 25 \\
\hline \multicolumn{2}{|l|}{ Farms eligible for analysis of rolling herd average (RHA) by bedding type } \\
\hline Farms with the same bedding in all pens during the study & 286 \\
\hline Excluded, not enrolled in DHI & 52 \\
\hline Excluded, did not report RHA & 7 \\
\hline Farms included in analysis & 227 \\
\hline \multicolumn{2}{|c|}{$\begin{array}{l}{ }^{1} \text { Inorganic bedding includes fresh sand }(n=155) \text {, recycled sand }(n=28) \text {, mixture of sands }(n=6) \text {, washed } \\
\text { sand }(n=3) \text {, fresh sand and lime }(n=2) \text {, and field-grade lime }(n=1) \text {. }\end{array}$} \\
\hline \multicolumn{2}{|c|}{$\begin{array}{l}{ }^{2} \text { Organic nonmanure bedding includes sawdust, shavings, and grain hulls }(\mathrm{n}=45) \text {; straw }(\mathrm{n}=7) \text {; mixtures of } \\
\text { organic beddings }(\mathrm{n}=5) \text {; straw or sawdust over lime or sand }(\mathrm{n}=3) \text {; and recycled paper products }(\mathrm{n}=2) \text {. }\end{array}$} \\
\hline \multicolumn{2}{|c|}{$\begin{array}{l}{ }^{3} \text { Manure based bedding includes digester solids }(n=13) \text {, biosolids }(n=4) \text {, composted manure }(n=4) \text {, manure } \\
\text { solids }(n=4) \text {, composted digester solids }(n=3) \text {, and separated solids }(n=1) \text {. }\end{array}$} \\
\hline \multicolumn{2}{|c|}{$\begin{array}{l}{ }^{4} \text { Inorganic bedding includes fresh sand }(n=121) \text {, recycled sand }(n=23) \text {, mixture of sands }(n=6) \text {, washed } \\
\text { sand }(n=3) \text {, fresh sand and lime }(n=2) \text {, and field-grade lime }(n=1) \text {. }\end{array}$} \\
\hline \multicolumn{2}{|c|}{$\begin{array}{l}{ }^{5} \text { Organic nonmanure bedding includes sawdust, shavings, and grain hulls }(\mathrm{n}=34) \text {; straw }(\mathrm{n}=7) \text {; mixtures of } \\
\text { organic beddings }(\mathrm{n}=4) \text {; straw or sawdust over lime or sand }(\mathrm{n}=2) \text {; and recycled paper products }(\mathrm{n}=2) \text {. }\end{array}$} \\
\hline${ }^{6}$ Manure based bedding includes digester solids $(n=11)$, compost & $=3), \mathrm{com}-$ \\
\hline
\end{tabular}

cators of milk quality and bedding. Some processors reported individual BMSCC and milk weights for each delivery of milk, whereas others reported monthly milk weighted average BMSCC for each farm. When individual BMSCC results were reported, researchers calculated a milk weighted BMSCC for each month. Seasons were defined as spring (March to May), summer (June to August), fall (September to November), and winter (December to February). For each farm-season combination, a simple average of the 3 monthly BMSCC results was calculated. Seasonal average BMSCC was transformed into bulk milk somatic cell score (BMSCS) using the equation: BMSCS = base 2 logarithm (BMSCC in cells per mL/100,000) + 3 (Shook, 1993), and used for analysis.

Some processors reported individual BMTBC results for each milk pickup, whereas others reported a single BMTBC for each farm each month. For farms report- ing $>1$ monthly BMTBC, one BMTBC was randomly selected from all BMTBC for each farm-month combination. Based on the 85th percentile of total bacterial count, monthly BMTBC were categorized as good $(\leq 10,000 \mathrm{cfu} / \mathrm{mL})$ or bad $(>10,000 \mathrm{cfu} / \mathrm{mL})$.

\section{Statistical Analysis}

Participating farms were categorized by the type of bedding used: inorganic bedding (IB), manure products (MB), other organic bedding (OB), or different bedding in different pens or at different times during the 2-yr study period (Table 1 ).

Statistical analyses were performed using SAS 9.4 (SAS Institute, 2014). Farm was the unit of analysis. Descriptive statistics using PROC MEANS, PROC UNIVARIATE, PROC FREQ, and PROC SGPLOT were used to verify data integrity, observe frequency 
distributions, and identify missing data. Biologically relevant categories of independent variables with $<5$ responses were combined for analysis. Continuous variables were stratified by type of bedding and analyzed using PROG GLM or PROC NPAR1WAY (when assumptions of linear models were not met). Multiple comparisons were adjusted using Tukey-Kramer for linear models and the Dwass, Steel, Critchlow-Fligner method for nonparametric models. Categorized variables were stratified by type of bedding and analyzed using PROC FREQ using a chi-squared test or Fisher's exact test (when the expected value of any cell in the contingency table was $<5$ ). All means are presented as mean \pm SE.

Development of Models. All multivariate models were built using a manual process that incorporated the biological and statistical relevance of each variable. Initially, all biologically relevant variables (survey responses) were assessed by screening for unconditional associations between each survey response and the relevant outcome variable. For each model, risk factors that were unconditionally associated with the outcome variable at $P \leq 0.25$ were tested for associations among predictor variables using chi-squared (for categorical variables) or correlation analysis (for continuous variables). If variables were highly associated $\left(\mathrm{R}^{2} \geq 0.60\right)$, the most biologically relevant variable was selected for further analysis. For each model, risk factors that were unconditionally associated with the outcome variable at $P \leq 0.25$ were offered for further multivariate modeling. Both forward and backward variable selection procedures were used to select the variables that remained in the final models. Confounding was assessed by examining the effect of each variable on the estimates of other explanatory variables. No variables included in any final model resulted in substantial changes among estimates of other explanatory variables $(\geq 20 \%$; Dohoo et al., 2012), indicating that confounding was not a problem. Biologically relevant first-order interactions among variables were offered for backward and forward variable selection to construct the final multivariate regression models. The Akaike information criterion (AIC; Akaike, 1969) was chosen for comparing models based on goodness of fit. All $P$-values for multiple comparisons within models were Tukey adjusted.

Models for Bulk Milk Somatic Cell Score. Initial modeling demonstrated that bedding type was associated with BMSCS (Table 2) and bedding management practices differed by bedding type, so 3 separate models were used to determine associations of bedding type (IB, OB, MB) with possible explanatory variables. Associations between selected survey responses (explanatory variables; Table 3 ) and BMSCS (response variable) were tested using repeated measures mixed models using PROC MIXED with an autoregressive covariance structure that included the intercept, year as a random effect, season, and the explanatory variable of interest. Explanatory variables unconditionally associated with BMSCS, and biologically relevant firstorder interactions were used to develop one multivariate repeated measures mixed model for each of the 3 bedding types.

Model for Rolling Herd Average. Associations between selected survey responses (explanatory variables; Table 4) and rolling herd average (RHA; response variable) were tested using a univariate regression model using PROC MIXED, which included the intercept and the explanatory variable of interest. Explanatory variables unconditionally associated with RHA and biologically relevant first-order interactions were used to develop the final multivariate model for RHA.

Model for Bulk Milk Total Bacteria Count. Association between bedding type (explanatory variable) and categorized BMTBC (response variable) was tested using repeated measures mixed logistic model using PROC GLIMMIX with an autoregressive covariance structure that included the intercept, year as a random effect, month, and bedding type (IB, OB, MB).

\section{RESULTS}

\section{Characteristics of Surveyed Farms}

Milk Production. Herds $(\mathrm{n}=325)$ milked between 255 and 8,100 lactating cows $(868 \pm 44)$ and contained a total of 282,235 lactating cows. Farms with $\geq 2,000$ milking cows $(n=20)$ represented $6.2 \%$ of farms, $23.5 \%$ of cows, and $24.0 \%$ of milk. Farms with 1,000 to 1,999 milking cows $(\mathrm{n}=61)$ represented 18.8, 28.7, and $28.4 \%$ of the farms, cows, and milk, respectively. Farms with 500 to 999 milking cows $(\mathrm{n}=140)$ represented $43.1,33.1$, and $32.5 \%$ of the farms, cows, and milk, respectively. The remaining 104 farms had $<500$ milking cows and represented 32.0, 14.8, and $15.1 \%$ of the farms, cows, and milk, respectively.

Daily milk production ranged from 11,340 to 317,151 $\mathrm{kg}(32,149 \pm 1.712 \mathrm{~kg})$ per farm with $37.0 \pm 0.3 \mathrm{~kg}$ of milk sold per cow per day (Table 5). Milk was sold from $98.2 \pm 0.07 \%$ of lactating cows (Table 5). Individual cow production was tested through DHI on $81.5 \%$ (n $=265$ ) of herds. Testing frequency varied from 1 - to 12 -mo intervals $(1.8 \pm 0.16)$. Rolling herd average on farms enrolled in DHI $(\mathrm{n}=257)$ ranged from 8,165 to $15,422 \mathrm{~kg}(12,584 \pm 75 \mathrm{~kg})$ with 8 farmers enrolled in DHI testing not reporting RHA.

Milking Management. The majority of farms had a written milking routine that was available in 
Table 2. Adjusted estimates of mean bulk milk $\mathrm{SCS}^{1}$ for all explanatory variables that remained in the final multivariate mixed repeated measures regression model for Wisconsin dairy farms $(\mathrm{n}=222)$ producing $\geq 11,340 \mathrm{~kg}$ of milk and using the same bedding in all pens during the study

\begin{tabular}{|c|c|c|c|c|c|c|c|c|}
\hline \multirow[b]{2}{*}{ Explanatory variable } & & \multirow[b]{2}{*}{$\mathrm{n}$} & \multirow[b]{2}{*}{ Estimate } & \multirow[b]{2}{*}{$\mathrm{SE}$} & \multirow{2}{*}{$\frac{\text { Type III }}{P \text {-value }}$} & \multicolumn{2}{|c|}{$95 \% \mathrm{CI}$} & \multirow{2}{*}{$\frac{\mathrm{SCC}^{2}}{(1,000 \text { cells } / \mathrm{mL})}$} \\
\hline & & & & & & Lower & Upper & \\
\hline Intercept & & & 3.70 & 0.107 & & & & 162 \\
\hline Cows with nonfunctioning mammary quarters, $\%$ & & 222 & 0.0142 & 0.0066 & 0.030 & 0.0013 & 0.0271 & - \\
\hline Categorical distribution & Levels & & & & & & & \\
\hline \multirow{2}{*}{ Year (random) } & 1 & 222 & 0.05 & 0.050 & & -0.05 & 0.14 & \\
\hline & 2 & 222 & -0.05 & 0.050 & & -0.14 & 0.05 & \\
\hline \multirow[t]{3}{*}{ Bedding } & $\mathrm{IB}^{3}$ & 152 & $3.90^{\mathrm{a}}$ & 0.080 & $<0.001$ & 3.75 & 4.06 & 187 \\
\hline & $\mathrm{MB}^{4}$ & 23 & $4.19^{\mathrm{b}}$ & 0.081 & & 3.96 & 4.42 & 228 \\
\hline & $\mathrm{OB}^{5}$ & 47 & $4.20^{\mathrm{b}}$ & 0.080 & & 4.02 & 4.39 & 230 \\
\hline \multirow[t]{4}{*}{ Season } & Spring & 222 & $4.02^{\mathrm{a}}$ & 0.081 & $<0.001$ & 3.86 & 4.18 & 203 \\
\hline & Summer & 222 & $4.25^{\mathrm{c}}$ & 0.080 & & 4.09 & 4.41 & 238 \\
\hline & Fall & 222 & $4.12^{\mathrm{b}}$ & 0.080 & & 3.96 & 4.28 & 217 \\
\hline & Winter & 222 & $4.01^{\mathrm{a}}$ & 0.080 & & 3.85 & 4.17 & 201 \\
\hline \multirow{2}{*}{ Type of postdip } & Iodine & 158 & $4.18^{\mathrm{b}}$ & 0.081 & 0.015 & 4.02 & 4.33 & 227 \\
\hline & Noniodine & 64 & $4.02^{\mathrm{a}}$ & 0.091 & & 3.84 & 4.20 & 203 \\
\hline \multirow{2}{*}{ Written milking protocol } & Present & 164 & $4.24^{\mathrm{b}}$ & 0.087 & $<0.001$ & 3.78 & 4.03 & 236 \\
\hline & Absent & 58 & $3.96^{\mathrm{a}}$ & 0.093 & & 4.06 & 4.53 & 195 \\
\hline \multirow{2}{*}{ Wipe off predip before milking } & Yes & 205 & $3.90^{\mathrm{a}}$ & 0.066 & $<0.001$ & 3.78 & 4.03 & 187 \\
\hline & No & 17 & $4.24^{\mathrm{b}}$ & 0.087 & & 4.06 & 4.53 & 236 \\
\hline \multicolumn{9}{|l|}{ Interaction } \\
\hline \multirow[t]{6}{*}{ WMP $\times$ bedding } & Present - IB & 120 & $4.09^{\mathrm{b}}$ & 0.078 & $<0.001$ & 3.94 & 4.24 & 213 \\
\hline & Present - MB & 15 & $4.50^{\mathrm{c}}$ & 0.144 & & 4.22 & 4.78 & 283 \\
\hline & Present - OB & 29 & $4.14^{\mathrm{bc}}$ & 0.104 & & 3.93 & 4.34 & 220 \\
\hline & Absent - IB & 32 & $3.72^{\mathrm{a}}$ & 0.101 & & 3.52 & 3.91 & 165 \\
\hline & Absent - MB & 8 & $3.89^{\mathrm{ab}}$ & 0.160 & & 3.58 & 4.20 & 185 \\
\hline & Absent - OB & 18 & $4.27^{\mathrm{bc}}$ & 0.125 & & 4.03 & 4.52 & 241 \\
\hline
\end{tabular}

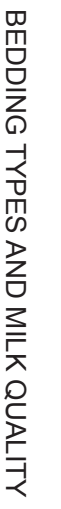

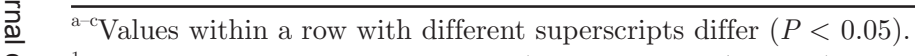

을 $\quad{ }^{1}$ Bulk milk somatic cell score $=\log _{2}$ (bulk milk SCC $\left./ 100,000\right)+3$

兽. $\quad{ }^{2}$ Back transformation to SCC, not used for analysis.

₹ ${ }^{3}$ Inorganic bedding.

ก). ${ }^{4}$ Manure bedding.

공 ${ }^{5}$ Organic, nonmanure bedding. 
Table 3. Variables assessed for unconditional association with bulk milk SCS

Type

Categories,

Responses for categorical variables

Z Rolling herd average, $\mathrm{kg}$

o Cows with milk discarded, $\%$

$\rightarrow \quad$ Cows milking on fewer than 4 quarters, \% Season

Farm size, cows

Parlor type

Frequency of DHI testing

$\mathrm{CMT}^{1}$ used on farm

Frequency of CMT use

CMT used on fresh cows

Continuous

Continuous

Continuous

Categorical

Categorical

Categorical

Categorical

Categorical

Categorical

CMT used on cows with clinical mastitis

Categorical

CMT used on cows with elevated SCC

$\begin{array}{ll}\text { CMT used on cows with elevated SCC } & \text { Categorical } \\ \text { Manager presence in parlor during milking } & \text { Categorical } \\ \text { Written milking protocol } & \text { Categorical }\end{array}$

Written milking protocol

Categorical

Type of postdip

Frequency of forestripping

Categorical

Dry teats before attaching milking unit Categorical

Use mechanical teat scrubber

Categorical

Use mechanical teat scrubber

Categorical

Segregate cows with elevated SCC

Categorical

Culture bulk milk

Categorical

Culture fresh cows

Categorical

Categorical
Categorical

Categorical

Culture cows with clinical mastitis

Bedding depth

Categorical

Frequency of adding bedding, $\mathrm{h}$

Continuous

Categorical

Frequency of adding bedding

Regularly remove and replace some bedding ${ }^{2}$

Regularly remove and replace all bedding

Categorical

Categorical

Type of bedding grooming

Categorical

Categorical

Frequency of grooming bedding in backs of stalls, $\mathrm{h} \quad$ Continuous

Categorical

Type of sand (inorganic bedding model only)

California Mastitis Test.

${ }^{2}$ All bedding in the back one-third of stalls removed and replaced at least once weekly.

${ }^{3}$ Farmers indicated that all bedding was removed from stalls and replaced at regular intervals.

Spring, summer, fall, winter

200 to 499,500 to $999,1,000$ to $1,999, \geq 2,000$

Parallel, rotary, herringbone or other

Monthly, less than once monthly

Yes, no

Daily, $>1 \times$ weekly, occasionally, never

Most or all, few or none

Most or all, few or none

Most or all, few or none

Always or portions of all milkings, only when problems are suspected or neve

Present, absent

Iodine, other

Iodine, other

Always, sometimes or never

Yes, no

Yes, no

Yes, no

$\geq$ Once monthly, less than monthly

Most or all, few or none

Most or all, few or none

Most or all, few or none

Deep, shallow

More than once weekly, every $7 \mathrm{~d}$ or more

Yes, no

Yes, no

Rake, mechanical

Yes, no

Fresh, recycled 
Table 4. Variables assessed for unconditional association with rolling herd average

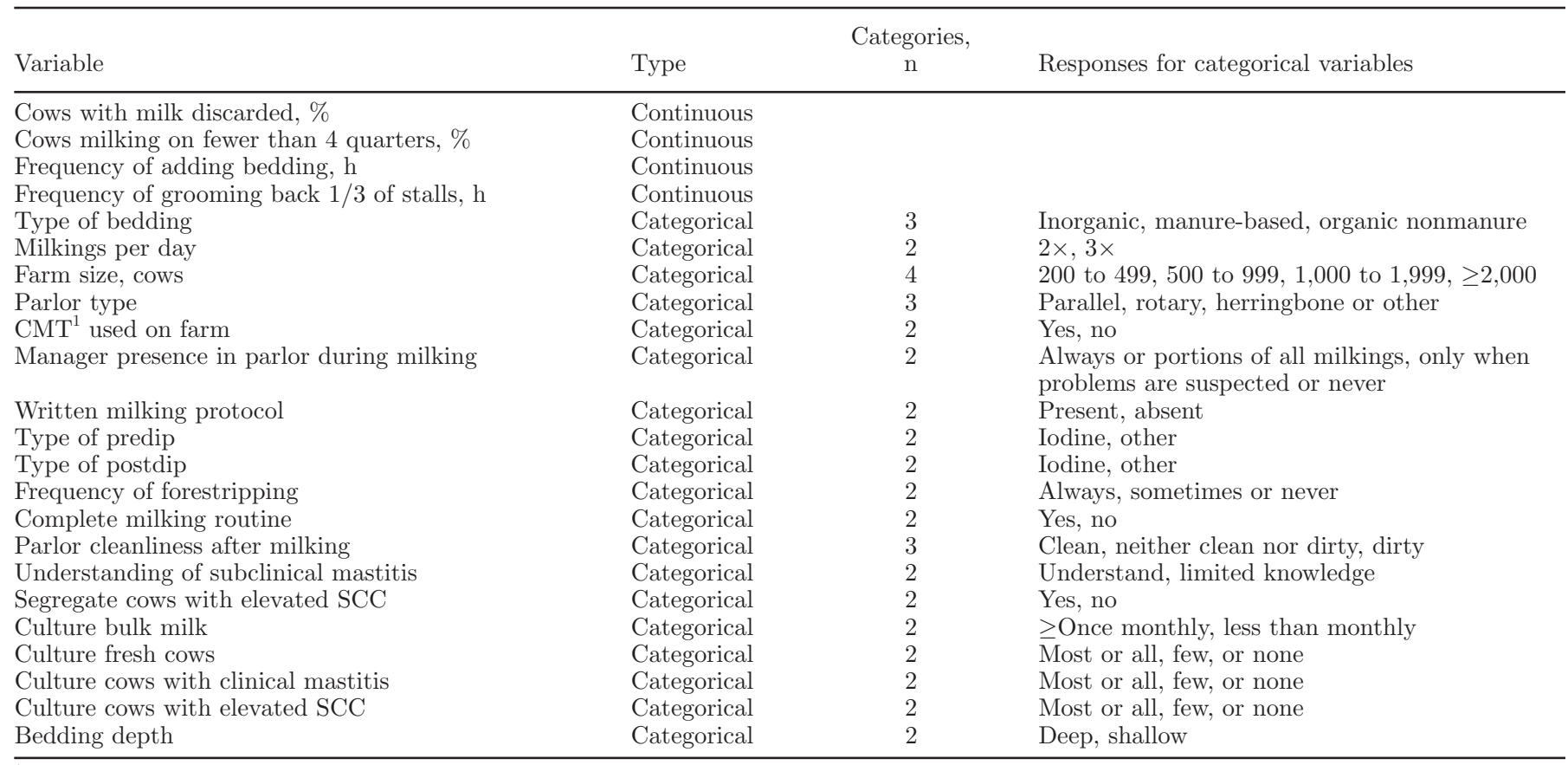

${ }^{1}$ California Mastitis Test.

the first language of the milking technicians (Table 6 ). Most farmers had adopted a complete milking routine consisting of premilking teat sanitation, removal of foremilk, drying teats with individual towels, and application of germicidal postdip (Table 6 ). Liquid preand postteat dips were used by 75 and $97 \%$ of farmers, respectively, with the remaining farms using foam teat dips. Few (10\%) farmers used teat scrubbers, and of those, only $18 \%$ dried teats before machine attachment (compared with $99.7 \%$ of other farms). Most managers were present in the milking parlor during portions of milking shifts, but some managers did not supervise milking during any shifts (Table 6).

Management of Mastitis. Most farms had a written protocol for mastitis treatments $(62.5 \%)$. When asked an open-ended question about how they identify subclinical mastitis $(\mathbf{S M}), 73.5 \%(\mathrm{n}=239)$ of all farmers demonstrated an understanding of SM without further prompting; of these, 31 did not check cows for SM. Of the 86 farmers who did not demonstrate knowledge of SM without prompting, 71 demonstrated understanding when prompted with common examples

Table 5. Characteristics of Wisconsin dairy farms $(\mathrm{n}=325)$ producing $\geq 11,340 \mathrm{~kg}$ of milk daily and participating in survey

\begin{tabular}{|c|c|c|c|c|c|}
\hline Outcome & Farms & Minimum & Mean & Maximum & $\mathrm{SE}$ \\
\hline Total daily production, $\mathrm{kg}$ & 325 & 11,340 & 32,149 & 317,515 & 1,712 \\
\hline DHI testing frequency, ${ }^{1}$ mo & 265 & 1 & 1.8 & 12 & 0.16 \\
\hline Milk sold per cow per day, $\mathrm{kg}$ & 325 & 21.5 & 37.0 & 49.9 & 0.26 \\
\hline Proportion of cows with milk not sold, $\%$ & 325 & 0.0 & 1.8 & 6.7 & 0.07 \\
\hline Cows milking on fewer than 4 quarters, ${ }^{3} \%$ & 312 & 0.0 & 4.7 & 30.0 & 0.23 \\
\hline Milk pickup frequency, h & 325 & 2 & 19.5 & 48 & 0.50 \\
\hline Bulk tank or trailer wash frequency, $\mathrm{h}$ & 325 & 2 & 21.6 & 48 & 0.52 \\
\hline
\end{tabular}

${ }^{1} 60$ herds did not participate in DHI.

${ }^{2} 8$ of 265 farmers participating in DHI did not report rolling herd average.

${ }^{3} 13$ farmers did not report percent of cows with nonfunctioning mammary quarters.

${ }^{4} 62$ farmers did not culture bulk milk. 
of methods used to detect SM; of these farmers, 48 indicated that they use individual cow SCC to detect SM. Two farmers believed that they did not have cows with SM present on their farms. Almost all farms enrolled in DHI (97.7\%) received individual cow SCC results on each test date. Cows with high SCC were segregated during milking on $32 \%$ of farms $(\mathrm{n}=104)$ with $75 \%$ of those farms using separate pens, $17.3 \%$ using hospital barns, and $7.7 \%$ using separate milking units. On farms with separate pens for cows with high SCC, 94.9\% milked these pens last.

Many farmers used bacteriological culturing to identify mastitis pathogens in both bulk milk and milk samples from individual cows. Approximately one-half $(53 \%)$ of farmers received bulk milk cultures once or more monthly, whereas $66 \%$ regularly received culture results from individual cow samples. Very few farmers used bacteriological culture for all fresh cows $(7 \%)$ or cows with elevated SCC (9\%), whereas about one-third of farmers received bacteriological culture results from all cows detected to have clinical mastitis.

The percent of cows with nonfunctioning mammary quarters was reported by $96.0 \%$ of surveyed farmers ( $\mathrm{n}$
$=312$ ). The proportion of cows with nonfunctioning mammary quarters ranged from 0 to $30 \%$. The 25 th, $50 \mathrm{th}, 75 \mathrm{th}$, and 90th percentiles of nonfunctioning mammary quarters were $2,4,6$, and $10 \%$, respectively.

Bedding Type and Management. Inorganic bedding was used most commonly (60\% of farms) followed by OB (19\%) and MB (9\%). Twelve percent of surveyed farms used different bedding in different pens or at different times during the study. Bedding on farms using the same type of bedding in all pens during the entire study period included IB: fresh sand $(\mathrm{n}=121)$, recycled sand $(\mathrm{n}=23)$, mixture of sands $(\mathrm{n}=6)$, washed sand $(\mathrm{n}=3)$, fresh sand and lime $(\mathrm{n}=2)$, and field-grade lime $(\mathrm{n}=1)$; OB: sawdust, shavings, and grain hulls $(\mathrm{n}=34)$, straw $(\mathrm{n}=7)$, mixtures of organic beddings $(\mathrm{n}=4)$, straw or sawdust over lime or sand $(\mathrm{n}=2)$, and recycled paper products $(n=2)$; and MB: digester solids $(\mathrm{n}=11)$, composted manure $(\mathrm{n}=4)$, biosolids ( $\mathrm{n}$ $=3$ ), composted digester solids $(\mathrm{n}=3)$, manure solids $(\mathrm{n}=3)$, and separated solids $(\mathrm{n}=1$; Table 1$)$. Farms on which $\mathrm{MB}$ was used contained more lactating cows $(1,502 \pm 187)$ than farms using IB $(849 \pm 62)$ or OB $(706 \pm 53 ; P<0.001)$ and had a greater proportion

Table 6. Milking routine and mastitis management practices on Wisconsin dairy farms $(\mathrm{n}=325)$ producing $\geq 11,340 \mathrm{~kg}$ of milk daily and participating in survey

\begin{tabular}{|c|c|c|c|c|}
\hline \multirow[b]{2}{*}{ Practice } & \multicolumn{2}{|c|}{ Total } & \multicolumn{2}{|c|}{ Within category } \\
\hline & $\mathrm{n}$ & $\%$ & $\mathrm{n}$ & $\%$ \\
\hline \multicolumn{5}{|l|}{ Predip use, type, and practices } \\
\hline Always predip & 322 & 99.1 & & \\
\hline Never predip & 3 & 0.9 & & \\
\hline \multicolumn{5}{|l|}{ Drying of teats by farmers using predip } \\
\hline Do not dry teats before machine attachment & & & 26 & 8.1 \\
\hline Dry teats before machine attachment & & & 296 & 91.9 \\
\hline \multicolumn{5}{|l|}{ Use a teat scrubber } \\
\hline Yes & 33 & 10.2 & & \\
\hline No & 292 & 89.8 & & \\
\hline \multicolumn{5}{|l|}{ Forestrip as part of milking routing } \\
\hline Always & 281 & 86.5 & & \\
\hline Sometimes & 29 & 8.9 & & \\
\hline Never & 15 & 4.6 & & \\
\hline \multicolumn{5}{|l|}{ Postdip use, type, and practices } \\
\hline Always postdip & 324 & 99.7 & & \\
\hline Sometimes postdip & 1 & 0.3 & & \\
\hline Complete milking routine $^{1}$ & 263 & 80.9 & & \\
\hline \multicolumn{5}{|l|}{ Written milking protocol } \\
\hline Yes & 240 & 73.8 & & \\
\hline No & 85 & 26.2 & & \\
\hline \multicolumn{5}{|l|}{ Manager in the parlor during milking } \\
\hline Always & 36 & 11.1 & & \\
\hline Portions of every milking shift & 93 & 28.6 & & \\
\hline Only during daytime milkings & 119 & 36.6 & & \\
\hline Only when problems are suspected & 20 & 6.2 & & \\
\hline Occasionally or never & 57 & 17.5 & & \\
\hline \multicolumn{5}{|l|}{ DHIA enrollment } \\
\hline Used DHI testing & 265 & 81.5 & & \\
\hline Did not use DHI testing & 60 & 18.5 & & \\
\hline
\end{tabular}

${ }^{1}$ Defined as use of a milking routine that always includes forestrip, predip, dry teats, and postdip. 
Table 7. Characteristics of Wisconsin dairy farms $(\mathrm{n}=286)$ producing $\geq 11,340 \mathrm{~kg}$ of milk daily and using the same bedding type during the study period stratified by bedding type

\begin{tabular}{|c|c|c|c|c|c|}
\hline Outcome & $\mathrm{n}$ & \multicolumn{3}{|c|}{ Bedding during study period } & $P$-value \\
\hline Mean herd size, $\mathrm{n}$ & 286 & $849^{\mathrm{a}}$ & $706^{\mathrm{a}}$ & $1502^{\mathrm{b}}$ & $<0.001$ \\
\hline Total daily production, $\mathrm{kg}$ & 286 & $32,331^{\mathrm{a}}$ & $24,492^{\mathrm{a}}$ & $53,175^{\mathrm{b}}$ & $<0.001$ \\
\hline DHI testing frequency, ${ }^{5}$ mo & 234 & 1.7 & 2.4 & 2.0 & 0.275 \\
\hline Proportion of cows with milk not sold, $\%$ & 286 & $1.6^{\mathrm{a}}$ & $1.9^{\mathrm{ab}}$ & $2.4^{\mathrm{b}}$ & 0.005 \\
\hline Cows with nonfunctioning mammary quarters, ${ }^{7} \%$ & 275 & 4.5 & 4.8 & 6.3 & 0.055 \\
\hline Bulk milk somatic cell count (BMSCC), ${ }^{8}$ cells $/ \mathrm{mL}$ & 230 & $198^{\mathrm{a}}$ & $220^{\mathrm{ab}}$ & $248^{\mathrm{b}}$ & 0.004 \\
\hline Bulk milk total bacteria count (BMTBC) ${ }^{9} \%$ & 230 & 78.2 & 75.1 & 76.1 & 0.088 \\
\hline Times bulk milk cultured annually, ${ }^{10} \mathrm{n}$ & 187 & 22.2 & 12.6 & 38.5 & 0.565 \\
\hline Milk pickup temperature, ${ }^{\circ} \mathrm{C}$ & 286 & 3.6 & 3.7 & 3.3 & 0.150 \\
\hline Milk pickup frequency, h & 286 & $19.6^{\mathrm{b}}$ & $21.6^{\mathrm{b}}$ & $13.3^{\mathrm{a}}$ & $<0.001$ \\
\hline
\end{tabular}

${ }^{\mathrm{a}, \mathrm{b}}$ Values within a row with different superscripts differ $(P<0.05)$.

${ }^{1}$ Inorganic bedding includes fresh sand $(\mathrm{n}=155)$, recycled sand $(\mathrm{n}=28)$, mixture of sands $(\mathrm{n}=6)$, washed sand $(\mathrm{n}=3)$, fresh sand and lime $(\mathrm{n}=2)$, and field-grade lime $(\mathrm{n}=1)$.

${ }^{2}$ Organic nonmanure bedding includes sawdust, shavings, and grain hulls $(\mathrm{n}=45)$; straw $(\mathrm{n}=7)$; mixtures of organic beddings $(\mathrm{n}=5)$; straw or sawdust over lime or sand $(\mathrm{n}=3)$; and recycled paper products $(\mathrm{n}=2)$.

${ }^{3}$ Manure based bedding includes digester solids $(\mathrm{n}=13)$, biosolids $(\mathrm{n}=4)$, composted manure $(\mathrm{n}=4)$, manure solids $(\mathrm{n}=4)$, composted digester solids $(\mathrm{n}=3)$, and separated solids $(\mathrm{n}=1)$.

${ }^{4} 39$ herds used different bedding in different pens or changed bedding over time.

${ }^{5}$ Includes IB $(\mathrm{n}=161)$, OB $(\mathrm{n}=47)$, MB $(\mathrm{n}=26)$.

${ }^{6}$ Includes IB $(\mathrm{n}=159)$, OB $(\mathrm{n}=44), \mathrm{MB}(\mathrm{n}=24)$.

${ }^{7}$ Includes IB $(\mathrm{n}=190)$, OB $(\mathrm{n}=61)$, MB $(\mathrm{n}=24)$.

${ }^{8}$ Includes IB $(\mathrm{n}=156)$, OB $(\mathrm{n}=49)$, MB $(\mathrm{n}=25)$.

${ }^{9}$ Includes IB $(\mathrm{n}=156)$, OB $(\mathrm{n}=49), \mathrm{MB}(\mathrm{n}=25)$; percent of BMTBC $\leq 10,000 \mathrm{cfu} / \mathrm{mL}$.

${ }^{10}$ Includes IB $(\mathrm{n}=129)$, OB $(\mathrm{n}=36), \mathrm{MB}(\mathrm{n}=22)$.

of cows with milk not sold $(2.4 \pm 0.30 \%)$ than farms bedding with IB $(1.7 \pm 0.08 \% ; P=0.005$; Table 7$)$. A tendency was observed for farms using MB to have a greater proportion of cows with nonfunctioning mammary quarters $(P=0.055$; Table 7$)$. As compared with farms with $\mathrm{MB}$ or $\mathrm{OB}$, farms with IB had greater milk sold per cow per day $(P=<0.001)$, greater RHA $(P$ $<0.001$ ), and a lesser proportion of cows with milk not sold (Table 7).

The frequency of adding new bedding to stalls varied by bedding type and depth of bedding in the stalls. Farms with IB were 15.7 and 1.8 times more likely to have deep bedding as compared with farms with $\mathrm{OB}$ and MB, respectively $(P<0.001)$. For stalls containing mattresses as a base, new MB or OB was added to stalls approximately twice as frequently as compared with IB (Table 8; $P<0.001$ ). Farms with IB added bedding to stalls less frequently (median of $168 \mathrm{~h}$ ) than farms with $\mathrm{OB}$ or MB (medians of 78 and $72 \mathrm{~h}$, respectively). Farms which used OB, removed and replaced bedding in the backs of stalls, or completely removed and replaced all bedding in stalls more often than those using IB $(P<0.001$; Table 8$)$. For deep-bedded stalls, farmers added MB approximately twice as frequently as IB $(P<0.001)$. For stalls with tires or sand traps, farmers added IB less frequently than in stalls without a base bedding or mattress $(P=0.023$; Table 8$)$.

Frequency of grooming bedding in the back of stalls was not associated with bedding type $(P=0.754)$ presence or type of base bedding materials $(P \geq 0.667)$, or type of stall grooming $(P \geq 0.062)$. For all types of bedding, the median frequency of stall grooming was $8 \mathrm{~h}$ (corresponding to milking frequency). Mechanical groomers were used on $41 \%$ of farms with IB in contrast to 29 and $3 \%$ of farms using $\mathrm{MB}$ and $\mathrm{OB}$, respectively (Table 6). No difference was found in the frequency of mechanical grooming by type of bedding $(P \geq 0.087)$, deep-bedded versus shallow-bedded stalls $(P \geq 0.579)$, or the frequency of removing and replacing bedding in stalls $(P \geq 0.087)$. For farms using the same bedding in all pens during the entire study period, no association was observed of bedding type with frequency of DHI testing, milk pickup temperature, or the frequency bacteriological cultures of bulk milk ( $P \geq 0.15$; Table 7$)$. 
Table 8. Bedding management practices on Wisconsin dairy farms $(\mathrm{n}=286)$ producing $\geq 11,340 \mathrm{~kg}$ of milk daily and using the same type of bedding for the study period stratified by bedding type, $\mathrm{h}$

\begin{tabular}{|c|c|c|c|c|}
\hline Item & $\begin{array}{l}\text { Inorganic, } \\
\text { mean } \pm \mathrm{SE}(\mathrm{n})\end{array}$ & $\begin{array}{l}\text { Manure products, } \\
\text { mean } \pm \text { SE }(n)\end{array}$ & $\begin{array}{l}\text { Organic nonmanure, } \\
\text { mean } \pm \text { SE }(\mathrm{n})\end{array}$ & $\begin{array}{l}P \text {-value } \\
\text { for row }\end{array}$ \\
\hline Grooming back of stalls, ${ }^{4} \mathrm{~h}$ & $10 \pm 0.9(188)$ & $12 \pm 2.1(28)$ & $10 \pm 1.5(61)$ & 0.754 \\
\hline Mechanical grooming, ${ }^{5} \mathrm{~h}$ & $94 \pm 12.5(79)$ & $49 \pm 24.4(18)$ & $59 \pm \ddagger(1)^{*}$ & 0.109 \\
\hline Remove and replace back one-third of stall, ${ }^{6} \mathrm{~h}$ & $416^{\mathrm{b}} \pm 60.5(55)$ & $168^{\mathrm{ab}} \pm 139.1(23)$ & $39^{\mathrm{a}} \pm 85.7(23)$ & $<0.001$ \\
\hline Remove and replace all, ${ }^{7} \mathrm{~h}$ & $450^{\mathrm{b}} \pm 65.6(11)$ & $205^{\mathrm{b}} \pm 80.3(10)$ & $41^{\mathrm{a}} \pm 60.7(10)$ & $<0.001$ \\
\hline Bedding addition, $\mathrm{h}$ & $161^{\mathrm{b}} \pm 5.2(195)$ & $71^{\mathrm{a}} \pm 12.3(62)$ & $79^{\mathrm{a}} \pm 8.9(29)$ & $<0.001$ \\
\hline \multicolumn{5}{|c|}{$\begin{array}{l}\text { Frequency of adding new bedding stratified by base bedding } \\
\text { material and bedding management practices }\end{array}$} \\
\hline \multicolumn{5}{|l|}{ Base bedding } \\
\hline Mattress & $133^{\mathrm{b}, \mathrm{y}} \pm 11.6(21)$ & $67^{\mathrm{a}} \pm 13.1(15)$ & $76^{\mathrm{a}} \pm 8.3(58)$ & $<0.001$ \\
\hline Tires or sand traps & $201^{\mathrm{z}} \pm 32.5(18)$ & & $192 \pm 168.0(2)^{*}$ & \\
\hline None & $160^{\mathrm{b}, \mathrm{y}} \pm 5.5(156)$ & $75^{\mathrm{a}} \pm 11.5(14)$ & $40 \pm 16.0(2)^{*}$ & $<0.001$ \\
\hline$P$-value for column & 0.023 & 0.374 & & \\
\hline \multicolumn{5}{|l|}{ Method of replacing bedding } \\
\hline Never replace all bedding & $163^{\mathrm{b}} \pm 7.2(139)$ & $80^{\mathrm{a}} \pm 10.7(21)$ & $88^{\mathrm{a}} \pm 11.1(39)$ & $<0.001$ \\
\hline Replace in backs of stalls & $162^{\mathrm{b}} \pm 8.6(44)$ & $54 \pm 30.0(2)^{*}$ & $47^{\mathrm{a}} \pm 12.8(13)$ & $<0.001$ \\
\hline Replace all bedding & $129^{\mathrm{b}} \pm 15.1(11)$ & $42^{\mathrm{a}} \pm 9.7(6)$ & $86^{\mathrm{ab}} \pm 31.5(10)$ & 0.007 \\
\hline Differs by pen or over time & $120 \ddagger(1)^{*}$ & - & & \\
\hline$P$-value for column & 0.384 & 0.792 & 0.087 & \\
\hline \multicolumn{5}{|l|}{ Type of grooming } \\
\hline Rake & $173^{\mathrm{b}, \mathrm{y}} \pm 8.2(114)$ & $69^{\mathrm{a}} \pm 16.7(11)$ & $80^{\mathrm{a}} \pm 9.2(61)$ & $<0.001$ \\
\hline Mechanical groomer & $143^{\mathrm{b}, \mathrm{z}} \pm 6.5(78)$ & $7^{\mathrm{a}} \pm 9.9(18)$ & $8 \ddagger(1)^{*}$ & $<0.001$ \\
\hline Do not groom bedding & $168 \pm 0.0(3)^{*}$ & - & - & \\
\hline$P$-value for column & 0.008 & 0.647 & & \\
\hline
\end{tabular}

-value for column

0.647

${ }^{\mathrm{y}, \mathrm{z}}$ Values within a column within a category with different superscripts differ $(P<0.05)$

${ }^{1}$ Inorganic bedding includes fresh sand $(\mathrm{n}=155)$, recycled sand $(\mathrm{n}=28)$, mixture of sands $(\mathrm{n}=6)$, washed sand $(\mathrm{n}=3)$, fresh sand and lime $(\mathrm{n}=2)$, and field-grade lime $(\mathrm{n}=1)$. ${ }^{2}$ Organic nonmanure bedding includes sawdust, shavings, and grain hulls $(\mathrm{n}=45)$; straw $(\mathrm{n}=7)$; mixtures of organic beddings $(\mathrm{n}=5)$; straw or sawdust over lime or sand $(\mathrm{n}=$ $3)$; and recycled paper products $(\mathrm{n}=2)$.

${ }^{3}$ Manure based bedding includes digester solids $(\mathrm{n}=13)$, biosolids $(\mathrm{n}=4)$, composted manure $(\mathrm{n}=4)$, manure solids $(\mathrm{n}=4)$, composted digester solids $(\mathrm{n}=3)$, and separated solids $(\mathrm{n}=1)$.

${ }^{4} 9$ did not groom backs of stalls.

${ }^{5} 188$ did not use mechanical bedding groomers.

${ }^{6} 100$ did not remove and replace bedding in back one-third of stalls.

${ }^{7} 259$ did not remove and replace all bedding in stalls.

${ }^{8} \mathrm{~A}$ dash indicates no farms within category.

†Standard error not reported for single observations

*Excluded from analysis due to sparse data. 


\section{Analyses of BMSCS by Bedding Type}

For the 2-yr study period, processors reported a median of 656 BMSCC results per farm. During the study period, all farms were in compliance with US SCC regulations. For 212 of 230 farms (92.5\%) using the same bedding in all pens during the study, all 3-mo geometric mean BMSCC were under the EU limit of 400,000 cells $/ \mathrm{mL}$.

Based on relationships between explanatory variables and BMSCS, variables eligible for inclusion in the 3 multivariate models (IB, OB, MB) for BMSCS included season (eligible for IB, OB, MB), proportion of cows with milk discarded or not sold (eligible for $\mathrm{IB}, \mathrm{MB}$ ), proportion of cows with nonfunctioning mammary quarters (eligible for IB, OB, MB), manager presence during milking (eligible for $\mathrm{IB}, \mathrm{OB}$ ), written milking protocol (WMP; eligible for IB, OB, MB), type of predip (eligible for IB), type of postdip (eligible for IB, OB), dry teats (eligible for IB), segregate cows with elevated SCC (eligible for IB, MB), culture bulk milk (eligible for IB), culture cows with clinical mastitis (eligible for IB), bedding depth (eligible for IB), frequency of adding bedding (eligible for IB), removal and replacement of bedding in back one-third of stalls (eligible for OB), type of bedding grooming (eligible for IB), and type of sand (eligible for IB).

Inorganic Bedding. Data from 151 farms using IB were used to determine associations of eligible management factors and BMSCS. Five of 156 farms originally considered eligible for this model were excluded because 2 farms did not groom bedding and 3 farms did not have complete BMSCS results. Of explanatory variables eligible for entry into the BMSCS model, season, frequency of adding bedding, WMP, drying teats before attaching the milking unit, type of grooming of bedding, and depth of bedding remained in the final model. No interactions remained in the final model (Table 9). Bulk milk SCS was least in winter and spring, intermediate in fall, and greatest in summer $(P<0.001)$. The BMSCC for farms using IB was $0.15 \log _{2}$ units greater when bedding was added more than once weekly, 0.35 $\log _{2}$ units greater when teats were not dried before machine attachment, and $0.35 \log _{2}$ units lesser when a WMP was not present on the farm (Table 9). All 13 farms with IB which did not dry teats before milking unit attachment used teat scrubbers. Of farms using IB and teat scrubbers $(\mathrm{n}=14)$, only 1 farm also dried teats before milking unit attachment. A tendency was found for greater BMSCS when stalls were deep bedded $(P=0.065)$. Bulk milk SCS was not associated with type of grooming of bedding $(P=0.74)$, but model fit was improved with the inclusion of this variable (AIC $=16.4$ vs. 24.9). All model assumptions were satisfied.
Nonmanure Organic Bedding. Data from 48 farms using $\mathrm{OB}$ was used to determine associations of eligible management factors with BMSCS. One of 49 farms originally eligible was excluded from analysis because complete BMSCS results were not available. Of explanatory variables eligible for entry into the BMSCS model, percent of cows with nonfunctioning mammary quarters, season, presence of a manger during milking, and regular removal and replacement of bedding in the back one-third of stalls remained in the final multivariate model. No interactions remained in the final model. Bulk milk SCS was least in the winter and spring, intermediate in the fall, and greatest in the summer $(P<$ 0.001). The BMSCC for farms using OB was $0.37 \log _{2}$ units greater when managers were present during all milking shifts and $0.33 \log _{2}$ units greater when the back one-third of stalls were not cleaned out at least once weekly (Table 10). Increasing the percentage of cows with nonfunctioning mammary quarters by $1 \%$ tended to be associated with increased BMSCC $(P=0.069)$. All model assumptions were satisfied and model fit was satisfactory $(\mathrm{AIC}=7.0)$.

Manure-Based Organic Bedding. Data from 23 farms using MB was used to determine associations of eligible management factors with BMSCS. Two of 25 farms eligible for screening models were excluded from analysis because BMSCS results were not available in each period. Of explanatory variables eligible for entry into the BMSCS model, the percentage of cows with milk discarded, season, and presence of a WMP remained in the final multivariate model. No interactions remained in the final model (Table 11). Bulk milk SCS was greater in the summer than other seasons $(P=$ 0.014 ) and BMSCS was $0.42 \log _{2}$ units greater with the presence of a WMP $(P=0.021)$. Each $1 \%$ increase in the percent of cows with milk discarded was associated with a 0.14 increase in BMSCS $(P=0.014)$. All model assumptions were satisfied, and model fit was satisfactory $(\mathrm{AIC}=30.1)$.

\section{Association of Bedding Type with Bulk Milk Total Bacteria Count}

Processors reported BMTBC results for 230 farms and 72,978 individual BMTBC test results were received. No farms were out of compliance with PMO or EU standards for BMTBC during the 2-yr period. The distribution of total bacterial count values was $\leq 100,000 \mathrm{cfu} / \mathrm{mL}(98 \%), \leq 25,000 \mathrm{cfu} / \mathrm{mL}(93 \%)$, and $\leq 10,000 \mathrm{cfu} / \mathrm{mL}(85 \%)$. Bulk tank total bacterial count category was not associated with bedding type $(P=$ $0.787)$, bedding management practices $(P \geq 0.356)$, or herd management practices $(P \geq 0.113)$ included in the survey. 
Table 9. Adjusted estimates of mean bulk milk somatic cell score for all explanatory variables that remained in the final multivariate mixed repeated measures regression model for Wisconsin dairy farms $(\mathrm{n}=151)$ producing $\geq 11,340 \mathrm{~kg}$ of milk daily and using inorganic ${ }^{1}$ bedding in all pens during the study period (linear score)

\begin{tabular}{|c|c|c|c|c|c|c|c|c|}
\hline \multirow[b]{2}{*}{ Explanatory variable } & \multirow[b]{2}{*}{ Levels } & \multirow{2}{*}{$\begin{array}{l}\text { Farms, } \\
\text { n }\end{array}$} & \multirow[b]{2}{*}{ Estimate } & \multirow[b]{2}{*}{$\mathrm{SE}$} & \multirow{2}{*}{$\begin{array}{l}\text { Type III } \\
P \text {-value }\end{array}$} & \multicolumn{2}{|c|}{$95 \%$ CI } & \multirow{2}{*}{$\frac{\mathrm{SCC}^{2}}{(1,000 \text { cells } / \mathrm{mL})}$} \\
\hline & & & & & & Lower & Upper & \\
\hline Intercept & & & 3.64 & 0.106 & & & & 156 \\
\hline \multirow{2}{*}{ Year (random) } & 1 & 151 & 0.06 & 0.062 & & -0.06 & 0.18 & \\
\hline & 2 & 151 & -0.06 & 0.062 & & -0.18 & 0.06 & \\
\hline \multirow[t]{4}{*}{ Season $^{3}$} & Spring & 151 & $3.82^{\mathrm{a}}$ & 0.095 & $<0.001$ & 3.73 & 4.11 & 177 \\
\hline & Summer & 151 & $4.05^{\mathrm{c}}$ & 0.095 & & 3.64 & 4.01 & 207 \\
\hline & Fall & 151 & $3.91^{\mathrm{b}}$ & 0.095 & & 3.87 & 4.24 & 188 \\
\hline & Winter & 151 & $3.81^{\mathrm{a}}$ & 0.095 & & 3.63 & 4.00 & 175 \\
\hline \multirow[t]{2}{*}{ Frequency of adding bedding } & Every 7 or more $d$ & 107 & $3.83^{\mathrm{a}}$ & 0.094 & 0.039 & 3.64 & 4.01 & 178 \\
\hline & More than $1 \times$ weekly & 44 & $3.98^{\mathrm{b}}$ & 0.108 & & 3.77 & 4.19 & 197 \\
\hline \multirow[t]{2}{*}{ Written milking protocol } & Present & 119 & $4.08^{\mathrm{b}}$ & 0.092 & $<0.001$ & 3.89 & 4.26 & 211 \\
\hline & Absent & 32 & $3.73^{\mathrm{a}}$ & 0.112 & & 3.51 & 3.95 & 166 \\
\hline \multirow[t]{2}{*}{ Dry teats before attaching milking unit } & Yes & 138 & $3.73^{\mathrm{a}}$ & 0.081 & 0.002 & 3.57 & 3.89 & 166 \\
\hline & No & 13 & $4.08^{\mathrm{b}}$ & 0.133 & & 3.82 & 4.34 & 211 \\
\hline \multirow{2}{*}{ Type of grooming of bedding } & Raked & 94 & 3.89 & 0.095 & 0.740 & 3.70 & 4.08 & 185 \\
\hline & Mechanical & 57 & 3.91 & 0.106 & & 3.71 & 4.12 & 188 \\
\hline \multirow[t]{2}{*}{ Depth of bedding } & Deep bedded & 125 & 3.99 & 0.090 & 0.065 & 3.81 & 4.16 & 199 \\
\hline & Shallow bedded & 26 & 3.82 & 0.117 & & 3.59 & 4.05 & 177 \\
\hline
\end{tabular}

${ }^{a-c}$ Estimates within a predictor with different superscripts differ. Tukey-adjusted $P<0.05$

${ }^{1}$ Inorganic bedding includes fresh sand $(\mathrm{n}=120)$, recycled sand $(\mathrm{n}=20)$, mixture of sands $(\mathrm{n}=6)$, washed sand $(\mathrm{n}=3)$, fresh sand and lime $(\mathrm{n}=1)$, and field-grade lime $(\mathrm{n}=1)$.

${ }^{2}$ Back transformation to SCC not used for analysis.

${ }^{3}$ Spring (March - May), summer (June - August), fall (September - November), and winter (December - February). 
Table 10. Adjusted estimates of mean bulk milk somatic cell score for all explanatory variables that remained in the final multivariate mixed repeated measures regression model for Wisconsin dairy farms $(\mathrm{n}=48)$ producing $\geq 11,340 \mathrm{~kg}$ of milk daily and using nonmanure organic ${ }^{1}$ bedding in all pens during the study period (linear score)

\begin{tabular}{|c|c|c|c|c|c|c|c|c|}
\hline \multirow[b]{2}{*}{ Explanatory variable } & \multirow[b]{2}{*}{ Levels } & \multirow{2}{*}{$\begin{array}{l}\text { Farms, } \\
\quad \mathrm{n}\end{array}$} & \multirow[b]{2}{*}{ Estimate } & \multirow[b]{2}{*}{$\mathrm{SE}$} & \multirow{2}{*}{$\begin{array}{l}\text { Type III } \\
P \text {-value }\end{array}$} & \multicolumn{2}{|c|}{$95 \%$ CI } & \multirow{2}{*}{$\frac{\mathrm{SCC}^{2}}{(1,000 \text { cells } / \mathrm{mL})}$} \\
\hline & & & & & & Lower & Upper & \\
\hline Intercept & & & 3.50 & 0.117 & & & & 141 \\
\hline Cows with nonfunctioning mammary quarters, $\%$ & & 48 & 0.020 & 0.011 & 0.069 & -0.0015 & 0.0406 & - \\
\hline \multirow{2}{*}{ Year (random) } & 1 & 48 & 0.00 & & & & & \\
\hline & 2 & 48 & 0.00 & & & & & \\
\hline \multirow[t]{4}{*}{ Season $^{3}$} & Spring & 48 & $3.95^{\mathrm{a}}$ & 0.064 & $<0.001$ & 3.82 & 4.07 & 193 \\
\hline & Summer & 48 & $4.20^{\mathrm{c}}$ & 0.065 & & 4.07 & 4.33 & 230 \\
\hline & Fall & 48 & $4.09^{\mathrm{b}}$ & 0.065 & & 3.96 & 4.21 & 213 \\
\hline & Winter & 48 & $3.95^{\mathrm{a}}$ & 0.064 & & 3.82 & 4.07 & 193 \\
\hline \multirow[t]{2}{*}{ Manager presence during milking } & $\begin{array}{l}\text { Never or when } \\
\text { problems suspected }\end{array}$ & 32 & $3.86^{\mathrm{a}}$ & 0.072 & 0.003 & 3.72 & 4.00 & 182 \\
\hline & $\begin{array}{l}\text { Always or portions } \\
\text { of all shifts }\end{array}$ & 16 & $4.23^{\mathrm{b}}$ & 0.101 & & 4.03 & 4.43 & 235 \\
\hline \multirow[t]{2}{*}{ Replace bedding in backs of stalls } & Regularly $^{4}$ & 17 & $3.88^{\mathrm{a}}$ & 0.100 & 0.008 & 3.69 & 4.08 & 184 \\
\hline & Not regularly & 31 & $4.21^{\mathrm{b}}$ & 0.073 & & 4.07 & 4.35 & 231 \\
\hline
\end{tabular}

Nonmanure organic bedding includes sawdust, shavings, and grain hulls $(\mathrm{n}=33)$; straw $(\mathrm{n}=7)$; mixtures of organic beddings $(\mathrm{n}=4)$; straw or sawdust over lime or sand $(\mathrm{n}=$

$2)$; and recycled paper products $(\mathrm{n}=2)$.

¿ $\quad{ }^{2}$ Back transformation to SCC not used for analysis.

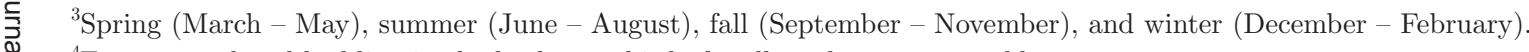

${ }^{4}$ Farmers replaced bedding in the back one-third of stalls at least once weekly. 


\section{Association of Bedding Type with Rolling Herd Average}

Data from 227 farms was used to determine associations of bedding type with RHA. Of explanatory variables eligible for entry into the RHA model (Table 12), the proportion of cows with nonfunctioning mammary quarters, bedding type, understanding of subclinical mastitis, and number of times the cows were milked each day remained in the final multivariate model. No interactions remained in the final model (Table 13). As compared with herds using IB, RHA were 771 and $1,153 \mathrm{~kg}$ less for herds using $\mathrm{OB}$ or $\mathrm{MB}$, respectively $(P$ $<0.001)$. The RHA was $353 \mathrm{~kg}$ greater for farms where the farmer understood subclinical mastitis as compared with farms where farmers had a limited understanding of subclinical mastitis $(P=0.017)$. Each $1 \%$ increase in cows with nonfunctioning mammary quarters was associated with a $57-\mathrm{kg}$ decrease in RHA $(P=0.001)$.

\section{DISCUSSION}

At the time that the study was conducted, the herds that participated in this study contained about $22.2 \%$ of the Wisconsin dairy herd $(1,267,000$ cows; USDANASS, 2014a) and represented a considerable proportion of milk produced in Wisconsin. In contrast to previous research using large Wisconsin farms (Pantoja et al., 2009; Oliveira et al., 2013), eligibility criteria for this study was based simply on the amount of milk produced per farm per day. The single eligibility criteria required farms to sell at least $11,340 \mathrm{~kg}$ of milk per day. This criterion was selected as it represented approximately one-half of the capacity of a milk tanker truck. Farms of this size are producing an increasing proportion of the total US milk supply. Dairy herds in the United States containing $\geq 200$ cows produced $76 \%$ of US milk in 2012 (USDA-NASS, 2014b). These farms use more intensive management strategies than smaller herds, and a better understanding of how bedding management on these farms influences productivity and milk quality is needed.

The high rate of participation (84\%) for farms meeting the eligibility criteria reduced selection bias and likely extends the reference population to comparably sized farms that use similar management practices in other regions. Several characteristics of study farms indicate that this group of larger herds used more intensive and technologically advanced management practices as compared with the general US dairy herd population. In contrast to the study herds, only 22 and $4 \%$ of US dairy farms are estimated to use IB and MB, respectively (USDA, 2008a). Of study farms, only $8 \%$ milked cows twice daily in contrast to approximately 
$59 \%$ of US dairy herds containing $\geq 500$ milking cows (USDA, 2008b). Standardized milking practices are highly adopted by Wisconsin dairy farmers of all herd sizes, indicating wide acceptance of these practices (Rodrigues et al., 2005). Recommended best management practices for milking were highly adopted in study herds and were similar or greater than adoption by US dairy farms containing >500 milking cows (USDA, $2008 \mathrm{~b})$. Similar proportions of herds used forestripping $(86.5 \%$ of study herds versus $83.5 \%$ of US herds milking $\geq 500$ cows). However, a greater proportion of study herds adopted both pre- $(99.1 \%)$ and postdipping $(99.7 \%)$ as compared with pre- $(80.2 \%)$ and postdipping (about $95 \%$ ) performed on US herds milking $\geq 500$ cows (USDA, 2008b).

Dairy farms need to produce high quality milk to maintain market access (Rowbotham, 2000; Norman et al., 2011; McCarty, 2015). In the United States, raw milk quality is regulated by the Pasteurized Milk Ordinance (PMO; US-FDA, 2011). The PMO establishes limits of 750,000 cells $/ \mathrm{mL}$ and 100,000 cfu/mL for BM$\mathrm{SCC}$ and BMTBC, respectively.

Milk quality standards of many dairy processors in Wisconsin are generally much more stringent than regulatory limits set in the PMO because minimizing BMSCC and BMTBC dramatically affects the final quality of dairy products (Boor and Murphy, 2002; Barbano et al., 2006) and allows US processors to gain access to export markets, which accounted for $15.4 \%$ of all sales of domestic production in 2013-2014 (US Dairy Export Council, 2015). Although some Wisconsin milk manufacturers do not export their core products such as cheese and butter, most of the products made from the byproduct streams of manufacturing processes (such as whey) are exported or comingled with product which may be exported. To maintain the ability to export byproducts, individual farms must maintain a USDA export certificate that mandates compliance with EU milk quality regulations. European Union milk quality guidelines require that farms maintain a geometric mean $\mathrm{SCC}<400,000$ cells $/ \mathrm{mL}$ for 3 consecutive months and a geometric mean total bacterial count $<100,000$ $\mathrm{cfu} / \mathrm{mL}$ for 2 consecutive months (Europa, 2009). Thus, the majority of milk produced in Wisconsin is required to comply with EU standards, effectively making the FDA BMSCC and BMTBC requirements in the PMO superfluous for many farms.

In this study, $100 \%$ of farms complied with US milk quality regulations for the 2-yr study period. Whereas $100 \%$ of farms complied with EU BMTBC regulations, 3 farms (2 using $\mathrm{MB}$ and 1 using $\mathrm{OB}$ ) were potentially out of compliance with EU BMSCC standards. The 3 farms that were potentially out of compliance could have requested derogations from USDA for up to $1 \mathrm{yr}$ while they worked to improve BMSCC. The $1.2 \%$ of study herds that were potentially out of compliance

Table 12. Unadjusted estimates and mean rolling herd average ${ }^{1}$ for all explanatory variables that were eligible for inclusion in multivariate models for Wisconsin dairy farms $(\mathrm{n}=227)$ producing $\geq 11,340 \mathrm{~kg}$ of milk daily $(\mathrm{kg})$

\begin{tabular}{|c|c|c|c|c|c|}
\hline Explanatory variable & Levels & $\mathrm{n}$ & Estimate & $\mathrm{SE}$ & $P$-value \\
\hline \multirow{2}{*}{ Bedding } & $\mathrm{IB}^{2}$ & 159 & 12,870 & 86.68 & $<0.001$ \\
\hline & $\mathrm{OB}^{3}$ & 44 & 12,025 & $1,644.77$ & 0.031 \\
\hline \multirow[t]{2}{*}{ California Mastitis Test used on the farm } & Yes & 171 & 12,298 & 155.19 & 0.022 \\
\hline & No & 56 & 12,686 & 88.81 & \\
\hline Frequency of forestripping & Always & 201 & 12,654 & 81.81 & \\
\hline Type of predip $^{5}$ & Noniodine & 84 & 12,750 & 124.65 & \\
\hline \multirow[t]{2}{*}{ Type of postdip ${ }^{6}$} & Iodine & 160 & 12,467 & 90.99 & 0.008 \\
\hline & Noniodine & 65 & 12,921 & 142.75 & \\
\hline \multirow[t]{2}{*}{ Understanding of subclinical mastitis } & Understood & 153 & 12,739 & 93.27 & 0.006 \\
\hline & Limited knowledge & 74 & 12,283 & 134.11 & \\
\hline \multirow[t]{2}{*}{ Milkings per day } & 2 & 22 & 11,907 & 245.55 & 0.004 \\
\hline & 3 & 205 & 12,664 & 80.44 & \\
\hline
\end{tabular}

\footnotetext{
${ }^{1}$ Rolling herd average from DHI records.

${ }^{2}$ Inorganic bedding includes fresh sand $(\mathrm{n}=122)$, recycled sand $(\mathrm{n}=26)$, mixture of sands $(\mathrm{n}=6)$, washed sand $(\mathrm{n}=3)$, fresh sand and lime $(\mathrm{n}=1)$, and field-grade lime $(\mathrm{n}=1)$.

${ }^{3}$ Organic nonmanure bedding includes sawdust, shavings, and grain hulls $(\mathrm{n}=30)$; straw $(\mathrm{n}=6)$; mixtures of organic beddings $(\mathrm{n}=5)$; straw or sawdust over lime or sand $(\mathrm{n}=2)$; and recycled paper products $(\mathrm{n}=1)$.

${ }^{4}$ Manure based bedding includes digester solids $(\mathrm{n}=14)$, biosolids $(\mathrm{n}=2)$, composted manure $(\mathrm{n}=3)$, manure solids $(\mathrm{n}=2)$, composted digester solids $(\mathrm{n}=2)$, and separated solids $(\mathrm{n}=1)$.

${ }^{5}$ One farm did not use predip.

${ }^{6}$ One farm did not use postdip.
} 
with EU standards for BMSCC is far less than previous estimates (7.8 to 16.1\%; Norman et al., 2011). Better milk quality and a greater level of compliance with EU milk quality standards by study herds is likely due partly to greater adoption of best management practices by larger herds (Wells and Ott, 1998; Jayarao et al., 2004; Norman et al., 2011) and partly in response to pressure from milk processors as they prepared to ensure compliance with EU standards that began on January 1, 2012.

The BMSCC is well known to be greatest in summer and least during winter and spring primarily due to environmental conditions that encourage growth of mastitis pathogens during warmers seasons (Ruegg and Tabone, 2000; Olde Riekerink et al., 2007; Archer et al., 2013). As expected, seasonality was significant in all 3 BMSCS models, indicating that seasonality in BMSCC is not dependent upon the type of bedding used within the study population.

Drying of teats before attaching milking units is a recommended best management practice and was highly adopted by herds that participated in this study (Moxley et al., 1978; Galton et al., 1986; Johnson, 2000). For study herds that used IB, drying teats before attaching milking units was associated with a $0.35 \log _{2}$ units lower BMSCC. Although it is likely that a similar association existed on herds using other bedding types, the high adoption of this practice in the smaller number of herds using other types of bedding did not allow for testing this association. Only 1 farm using $\mathrm{OB}$ and 2 farms using $\mathrm{MB}$ reported that they did not dry teats before attaching milking units. Use of teat scrubbers and not drying teats were correlated $(\mathrm{r}=0.96)$ on farms with IB where all farms $(n=13)$ not drying teats also used teat scrubbers and only 1 farm using teat scrubbers dried teats. The current study was not able to model both of these correlated explanatory variables. Further research focusing on the effectiveness of teat scrubbers with or without teat drying is warranted.

For herds using both IB and MB, BMSCS was greater for farms that had a WMP. Greater BMSCS on farms with written protocols, which outline work procedures and define best practices, is counterintuitive. Other research has also found contradictory associations with this variable. A previous study of 180 Wisconsin herds enrolled in milk quality management teams (Rodrigues et al., 2005) reported that WMP were present in a greater proportion of herds with low $(<250,000$ cells / $\mathrm{mL}$ ) or high ( $>400,000$ cells $/ \mathrm{mL})$ BMSCC as compared with herds with medium BMSCC (250,000 to 400,000 cells $/ \mathrm{mL}$ ). However, no herds enrolled in the current study had BMSCC $>400,000$ cells $/ \mathrm{mL}$. It is likely that the presence of a WMP is irrelevant for herds that do not adequately implement the protocol and assessment 
of the actual milking procedures would be a more useful variable to include in future models. It is also possible that this is a spurious finding as cross-sectional observational studies can identify the significance and strength of associations between variables but cannot define the direction of association nor assign causality (Dohoo et al., 2012). It is possible that farmers who experienced milk quality problems worked with consultants to develop a WMP as a mechanism to reduce mastitis and improve milk quality. The presence of the WMP, without proper implementation would not be expected to have had positive results and it is plausible that farms with increased BMSCC in the past were more likely to have a WMP.

On farms using OB, increased BMSCS was unexpectedly associated with the presence of managers during milking. It is possible that on farms with well-trained milking technicians, management presence in the parlors on a frequent basis has a lesser effect on BMSCC as compared with farms that have poorer results. Our survey instrument did not contain questions that allowed us to further evaluate this relationship and additional research about the role of training, use of written protocols, and labor management is warranted.

Bedding is a primary reservoir for growth of most environmental mastitis pathogens and serves as a point of exposure of teats, so it is important to understand the relationship between pathogen populations in bedding and on teat skin (Hogan et al., 1990; Zdanowicz et al., 2004; Proietto et al., 2013). In vitro studies of the ability of sterilized bedding materials to support pathogen growth have shown that recycled manure can support the log growth phase for 0 to $24 \mathrm{~h}, 6$ to $24 \mathrm{~h}$, or no log growth for coliforms, Streptococcus uberis and Enterococcus faecium, respectively (Zehner et al., 1986; Godden et al., 2008). These studies reported log growth of coliforms for up to $48 \mathrm{~h}$ (followed by a stationary phase for up to $102 \mathrm{~h}$ ) in clean sand and wood products, but no log or stationary growth phases in these same bedding materials for streptococci (which began a death phase at the time of inoculation). These growth patterns demonstrate the ability of both organic and inorganic bedding to supply the necessary nutrients for pathogen growth for short periods of time. Kristula et al. (2008) reported that the number of total coliforms, Klebsiella spp., streptococci, and Escherichia coli were least at the time of placement of wood shavings into stalls (with mattresses) and continued to increase (when measured at $12 \mathrm{~h}$ intervals) up to $48 \mathrm{~h}$ after placement. In a study of mastitis pathogens in sand and sawdust bedding (Zdanowicz et al., 2004), growth in sawdust was similar to Kristula et al. (2008), with exponential growth of bacteria after placement through d 1. After the first day, bacterial growth continued at a slower rate through the rest of the trial periods. Our study found an association between decreased BMSCS and removal of $\mathrm{OB}$ from the back one-third of stalls at least once weekly. This relationship may have resulted from reduced exposure to mastitis pathogens in clean bedding. For farms using IB and OB, associations of regular removal and replacement of bedding and BMSCS could not be evaluated due to small sample sizes. Only 5 farms using IB replaced bedding at least once monthly and only 1 farm using MB replaced bedding more than 4 times per year. Kristula et al. (2005) measured potential mastitis pathogens in clean and recycled sand bedding and reported that quantities were least at time of placement of bedding into stalls and increased logarithmically until $1 \mathrm{~d}$ after placement. Zdanowicz et al. (2004) also reported that the number of potential mastitis pathogens cultured from sand bedding peaked $1 \mathrm{~d}$ after placement of bedding in stalls. Interestingly, the number of Streptococcus spp. remained constant through the end of 1 -wk trial periods $(\mathrm{n}=3)$ whereas the number of coliforms and Klebsiella declined by the end of the trial periods. Thus maximum exposure to pathogens in IB occurs approximately 1 to $2 \mathrm{~d}$ after new bedding is placed in stalls. In our study, the addition of new IB to stalls more than once weekly was associated with increased BMSCS. It is possible that frequent addition of new bedding supplied nutrients that maintained organisms in a logarithmic growth phase, rather than allowing the pathogens to consume available nutrients and enter a stationary or death phase, as suggested by Zdanowicz et al. (2004). On farms using IB, increased frequency of adding new bedding was associated with increased BMSCS; however, on farms using $\mathrm{OB}$, increased frequency of replacement was associated with decreased BMSCS. These seemingly contradictory associations are representative of the complexity of bedding management on large dairy farms. Of farms using OB, 35\% removed and replaced the bedding in the backs of stalls at least weekly. In contrast, of farms using IB, only $3 \%$ removed and replaced bedding at least weekly. Most farms using IB simply added new bedding to bedding already present in stalls. Differences in bedding management practices of farms using different types of bedding (Table 8) and differences in BMSCS related to bedding management practices suggest that further research about these complex relationships is necessary.

Several studies have shown strong positive correlations between the number and type of bacteria in bedding and on teat skin (Hogan et al., 1990, 1999; Hogan and Smith, 1997). Correlations between pathogen populations in bedding and teat skin have ranged from 0.36 (coliforms in sand bedding; Zdanowicz et al., 2004) to 0.97 (streptococci in sawdust plus an acidic condi- 
tioner; Proietto et al., 2013). The number and distribution of organisms found in bedding profoundly affects colonization of teat skin (Rendos et al., 1975; Hogan and Smith, 1997). In general, bacterial counts on teat skin have been reported to be greater for cows housed on organic bedding as compared with cows housed on inorganic bedding (Fairchild et al., 1982; Janzen et al., 1982; Zdanowicz et al., 2004). Studies of the association between bacterial populations in bedding and on teat skin have usually been of short duration, with cows exposed to each bedding for 1 to 3 wk (Hogan et al., 1990, 1999; Hogan and Smith, 1997). Although these short duration studies are sufficient to determine associations between bacterial populations of bedding and on teat skin, the exposure period is not long enough to be able to identify associations with the risk of mastitis. Results of our study indicate that bedding type is associated with indicators of mastitis including BMSCS and the percentage of cows with nonfunctioning mammary quarters (Table 2). Further research is needed to improve bedding management and reduce the risk of mastitis for herds that are using organic (OB or $\mathrm{MB}$ ) bedding.

As compared with herds included in previous studies (Borneman et al., 2015; O'Connell et al., 2015), herds included in this study had exceptionally good BMTBC and were similar to an earlier study of large Wisconsin dairies (Pantoja et al., 2009). Borneman et al. (2015) reported that the 75th percentile of BMTBC for 1,301 Wisconsin grade A farms subjected to regulatory survey in 2012 was 25,000 cells/mL. However, farms included in that study were a subset of all Wisconsin grade A dairy farms and were not selected based on farm size. Only $7 \%$ of BMTBC in our study were $>25,000 \mathrm{cfu} /$ $\mathrm{mL}$ and the technological advantages of management practices used by larger dairy herds on BMTBC is apparent. In contrast, in a study that included almost all Irish dairy herds $(\mathrm{n}=10,819)$, O'Connell et al. (2015) reported that the 75 th percentile for BMTBC herds ranged from 25,000 to $30,000 \mathrm{cfu} / \mathrm{mL}$. However, the average Irish dairy herd contained only 55 milking cows, often stored milk in bulk tanks on farms for several days and used less rigorous methods of washing milking equipment. The quality of milk produced on Wisconsin and US farms may continue to improve as processor standards become more rigorous to meet consumer and export demands and milk production continues to shift from smaller to larger farms which tend to adopt newer technologies sooner.

The type of bedding used on farms was not associated with BMTBC. Management practices that result in production of high quality milk with minimal bacterial contamination are well documented and include proper udder hygiene and pre-milking sanitization, postmilk- ing sanitization, effective milking machine cleaning, adequate cooling, and storage of milk between 0 and $4.4^{\circ} \mathrm{C}$ (Reinemann et al., 1997; Reinemann, 2011). Maintaining optimal BMTBC is generally less complicated than maintaining optimal BMSCC. Unlike increased BMSCC, resolution of problems with increased BMTBC is typically accomplished by correction of equipment failures (such as malfunctioning cleaning processes) or procedural lapses (such as poor premilking sanitization of teats; Reinemann et al., 1997). Improvements in milking procedures, cleaning of equipment, and proper milk cooling can result in immediate and long-lasting improvements in BMTBC. In contrast to the long-term effect of mastitis on BMSCC (Keefe, 2012), resolution of the underlying problem causing increased BMTBC has little or no residual effect. Improvements in equipment, cooling technologies, or hygiene often result in BMTBC values that meet or exceed processor thresholds for maximizing quality premiums. Borneman, et al. (2015) were unable to show associations of official BMTBC counts and results of regulatory inspection visits that are used to verify compliance with the PMO, mostly likely because most milk processors in Wisconsin enforce more rigorous standards for BMTBC than required by regulators and herds that exceed processor threshold for BMTBC are often promptly visited by processor representatives. Bulk milk total bacterial count values that almost universally meet or exceed market and regulatory expectations indicate that most of the large dairy farms included in this study have implemented management practices necessary to control BMTBC to the point that it is no longer a milk quality issue for most of the surveyed farms.

The use of IB was associated with considerable increases in RHA, which would result in increased gross revenue from milk sales. The RHA of farms using IB were 761 and $1,153 \mathrm{~kg}$ greater than the RHA of farms using $\mathrm{OB}$ and $\mathrm{MB}$, respectively. The average farm included in this study contained 853 milking cows and the average milk price from May 2010 to April 2012 for Wisconsin dairy farms was $\$ 18.52$ per $46.36 \mathrm{~kg}$ of milk (USDA-AMS, 2015). Using these assumptions, the difference in RHA for herds using IB equates to additional annual gross revenue per cow of $\$ 304$ and $\$ 461$ as compared with herds using $\mathrm{OB}$ or $\mathrm{MB}$, respectively. Using the same assumptions, average gross revenue per cow for the 220 herds used in the RHA model was $\$ 5,074$, and this potential difference represents an additional potential of 6 to $9 \%$ in average annual gross milk sales per cow or $\$ 392,894$ per year for an average study farm. The large potential financial opportunity associated with use of IB warrants further research of the possible economic implications. Potential benefits associated with increased gross revenue need to be modeled 
against cost differences associated with management of different bedding materials.

Results of this study demonstrate the potential effect of mastitis on herd productivity and illustrate potential negative consequences on animal health based on bedding type. Rolling herd average of cows on farms using IB was greater than on farms using organic bedding (OB or $\mathrm{MB}$ ). The data included in this study suggest that at least part of the differences in productivity associated with different bedding types may be attributed to better udder health on farms using IB as contrasted with farms using OB or MB. Cows free of mastitis produce more milk than infected cows (Seegers et al., 2003; Bar et al., 2008). Study herds bedded with IB had a lesser BMSCS, indicating that the prevalence of subclinical mastitis was likely greater in herds using organic bedding (Schukken et al., 2003). Farms using MB had a greater percentage of cows with milk discarded, likely indicating a greater incidence of clinical mastitis, which necessitates discarding milk. Greater incidence of clinical mastitis on farms using MB contributes to less efficient milk production and may ultimately lead to farmers drying off individual mammary gland quarters of chronically affected cows (as evidenced by the tendency for a greater percentage of cows with nonfunctioning mammary quarters on farms using MB as compared with IB).

Possible causes of nonfunctioning mammary quarters include prepartum suckling, termination of production due to chronic mastitis, trauma, or intentional cessation of lactation due to chronic mastitis (Duraes et al., 1982). Except for a single study that focused on quarters which were nonfunctional at first parturition (Duraes et al., 1982), studies of the effects of nonfunctional quarters on milk production are lacking. In the present study, at the herd level, decreasing the prevalence of cows with nonfunctional mammary quarters by $1 \%$ was associated with a $57-\mathrm{kg}$ increase in RHA. The authors hypothesize that when nutritional management is optimized, the total number of functional alveoli in the udder may be a limiting factor for milk production, thus resulting in reduced production from animals with at least one nonfunctioning mammary quarter. Using the results from the multivariate RHA model, a reduction in the proportion of cows milking with fewer than 4 functioning mammary quarters by $1 \%$ would result in approximately $\$ 23.00$ in increased milk sales per cow annually. Approximately 5\% of study herds reported $>10 \%$ of milking cows with at least one nonfunctioning mammary quarter. For these herds, reducing this proportion to the study median of $4 \%$ would result in at least $\$ 136$ in additional annual milk sales per cow (\$115,926 per herd) for an average farm. Reducing the proportion of cows with at least one nonfunctioning mammary quarter could be accomplished through improved mastitis prevention strategies.

Due to the large scale of the farms that enrolled in this study, even modest improvements in productivity result in large changes in gross farm income. These improvements may justify investment in capital or labor to implement new processes or procedures (such as changing the type of bedding that is used). Although a complete financial analysis of the implications of changing the type of bedding is beyond the scope of this study, potential returns from implementing some of the practices associated with increased RHA or decreased BMSCS could result in considerably increased gross milk value and warrant consideration by farm owners.

\section{CONCLUSIONS}

Large Wisconsin dairy farms produce high-quality milk with minimal BMTBC and low BMSCC in part due to almost universal adoption of best management practices. Farms using IB (as compared with use of organic bedding) had greater RHA and better milk quality. Several management practices were associated with improved BMSCS. Farms using IB had lesser BMSCS when bedding was added at $>7$-d intervals and lesser BMSCS when teats were dried before attaching the milking unit. Production of higher quality milk on farms using IB had the potential to increase the value of each unit of milk produced. Further research is warranted into the relative economic value of using different bedding materials and the effect of bedding choice on animal health and well-being.

\section{ACKNOWLEDGMENTS}

The authors thank dairy owners and milk buyers for their participation in this project and the Grande Cheese Company (Brownsville, WI) for project funding.

\section{REFERENCES}

Akaike, H. 1969. Fitting autoregressive models for prediction. Ann. Inst. Stat. Math. 21:243-247.

Archer, S. C., F. Mc Coy, W. Wapenaar, and M. J. Green. 2013. Association of season and herd size with somatic cell count for cows in Irish, English, and Welsh dairy herds. Vet. J. 196:515-521.

Bar, D., L. W. Tauer, G. Bennett, R. N. González, J. A. Hertl, Y. H. Schukken, H. F. Schulte, F. L. Welcome, and Y. T. Gröhn. 2008. The cost of generic clinical mastitis in dairy cows as estimated by using dynamic programming. J. Dairy Sci. 91:2205-2214.

Barbano, D. M., Y. Ma, and M. V. Santos. 2006. Influence of raw milk quality on fluid milk shelf life. J. Dairy Sci. 89:E15-E19.

Boor, K. J., and S. C. Murphy. 2002. Microbiology of market milks. Pages 91-122 in Dairy Microbiology Handbook, 3rd ed. R. K. Robinson, ed. John Wiley \& Sons Inc., Hoboken, NJ. 
Borneman, D. L., K. Stiegert, and S. Ingham. 2015. Limitations of on-site dairy farm regulatory debits as milk quality predictors. J. Dairy Sci. 98:1526-1538.

Cook, N. B., T. B. Bennett, and K. V. Nordlund. 2005. Monitoring indices of cow comfort in free-stall-housed dairy herds. J. Dairy Sci. 88:3876-3885.

Costello, M., M. Rhee, M. P. Bates, S. Clark, L. O. Luedecke, and D. Kang. 2003. Eleven-year trends of microbiological quality in bulk tank milk. Food Prot. Trends 23:393-400.

Deluyker, H. A., J. M. Gay, and L. D. Weaver. 1993. Interrelationships of somatic cell count, mastitis, and milk yield in a low somatic cell count herd. J. Dairy Sci. 76:3445-3452.

DeVries, T. J., M. G. Aarnoudse, H. W. Barkema, K. E. Leslie, and M. A. G. von Keyserlingk. 2012. Associations of dairy cow behavior, barn hygiene, cow hygiene, and risk of elevated somatic cell count. J. Dairy Sci. 95:5730-5739.

Dohoo, I., W. Martin, and H. Stryhn. 2012. Methods in Epidemiologic Research. Ver. Inc., Charlottetown, Prince Edward Island, Canada.

Duraes, M. C., C. J. Wilcox, H. H. Head, and H. H. Van Horn. 1982 Frequency and effects on production of blind quarters in first lactation dairy cows. J. Dairy Sci. 65:1804-1807.

Europa. 2009. Regulation (EC) No. 853/2004 of the European Parliament and of the Council of 29 April 2004 laying down specific hygiene rules for food of animal origin (OJ L 226, 25.6.2004, p. 22) [with successive amendments and corrections consolidated]. Accessed Mar. 21, 2015. http://eur-lex.europa.eu/LexUriServ/ LexUriServ.do?uri=CONSLEG:2004R0853:20071114:EN:PDF

Fairchild, T. P., B. J. McArthur, J. H. Moore, and W. E. Hylton. 1982. Coliform counts in various bedding materials. J. Dairy Sci. 65:1029-1035.

Fulwider, W. K., T. Grandin, B. E. Rollin, T. E. Engle, N. L. Dalsted, and W. D. Lamm. 2008. Survey of dairy management practices on one hundred thirteen north central and northeastern United States dairies. J. Dairy Sci. 91:1686-1692.

Galton, D. M., L. G. Petersson, and W. G. Merrill. 1986. Effects of premilking udder preparation practices on bacterial counts in milk and on teats. J. Dairy Sci. 69:260-266.

Godden, S., R. Bey, K. Lorch, R. Farnsworth, and P. Rapnicki. 2008. Ability of organic and inorganic bedding materials to promote growth of environmental bacteria. J. Dairy Sci. 91:151-159.

Hogan, J., and K. L. Smith. 2012. Managing environmental mastitis Vet. Clin. North Am. Food Anim. Pract. 28:217-224.

Hogan, J. S., V. L. Bogacz, L. M. Thompson, S. Romig, P. S. Schoenberger, W. P. Weiss, and K. L. Smith. 1999. Bacterial counts associated with sawdust and recycled manure bedding treated with commercial conditioners. J. Dairy Sci. 82:1690-1695.

Hogan, J. S., and K. L. Smith. 1997. Bacteria counts in sawdust bedding. J. Dairy Sci. 80:1600-1605.

Hogan, J. S., K. L. Smith, K. H. Hoblet, D. A. Todhunter, P. S. Schoenberger, W. D. Hueston, D. E. Pritchard, G. L. Bowman, L. E. Heider, B. L. Brockett, and H. R. Conrad. 1989. Bacterial counts in bedding materials used on nine commercial dairies. J. Dairy Sci. 72:250-258.

Hogan, J. S., K. L. Smith, D. A. Todhunter, and P. S. Schoenberger. 1990. Bacterial counts associated with recycled newspaper bedding. J. Dairy Sci. 73:1756-1761.

Janzen, J. J., R. R. Bishop, A. B. Bodine, C. A. Caldwell, and D. W. Johnson. 1982. Composted dairy waste solids and crushed limestone as bedding in free stalls. J. Dairy Sci. 65:1025-1028.

Jayarao, B. M., S. R. Pillai, A. A. Sawant, D. R. Wolfgang, and N. V. Hegde. 2004. Guidelines for monitoring bulk tank milk somatic cell and bacterial counts. J. Dairy Sci. 87:3561-3573.

Johnson, A. P. 2000. A proper milking routine: The key to quality milk. Page 123 in Proc. Natl. Mastitis Council Mtg., Reno, NV. Natl. Mastitis Counc. Inc., Verona, WI.

Keefe, G. 2012. Update on control of Staphylococcus aureus and Streptococcus agalactiae for management of mastitis. Vet. Clin. Food Anim. 28:203-216.
Kristula, M. A., Z. Dou, J. D. Toth, B. I. Smith, N. Harvey, and M. Sabo. 2008. Evaluation of free-stall mattress bedding treatments to reduce mastitis bacterial growth. J. Dairy Sci. 91:1885-1892.

Kristula, M. A., W. Rogers, J. S. Hogan, and M. Sabo. 2005. Comparison of bacteria populations in clean and recycled sand used for bedding in dairy facilities. J. Dairy Sci. 88:4317-4325.

Lago, A., S. M. Godden, R. Bey, P. L. Ruegg, and K. Leslie. 2011. The selective treatment of clinical mastitis based on on-farm culture results: I. Effects on antibiotic use, milk withholding time, and short-term clinical and bacteriological outcomes. J. Dairy Sci. 94:4441-4456.

Makovec, J. A., and P. L. Ruegg. 2003. Results of milk samples submitted for microbiological examination in Wisconsin from 1994 to 2001. J. Dairy Sci. 86:3466-3472.

McCarty, K. K. 2015. What processors really need for milk qualityAnd why. Pages 92-94 in Natl. Mastitis Counc. Mtg. Proc., Memphis, TN. Natl. Mastitis Counc. Inc., Verona, WI.

Moxley, J. E., B. W. Kennedy, B. R. Downey, and J. S. T. Bowman. 1978. Survey of milking hygiene practices and their relationships to somatic cell counts and milk production. J. Dairy Sci. 61:16371644

Norman, H. D., J. E. Lombard, J. R. Wright, C. A. Kopral, J. M. Rodriguez, and R. H. Miller. 2011. Consequence of alternative standards for bulk tank somatic cell count of dairy herds in the United States. J. Dairy Sci. 94:6243-6256.

O'Connell, A., S. McParland, P. L. Ruegg, B. O'Brien, and D. Gleeson. 2015. Seasonal trends in milk quality in Ireland between 2007 and 2011. J. Dairy Sci. 98:3778-3790.

Olde Riekerink, R. G. M., H. W. Barkema, and H. Stryhn. 2007. The effect of season on somatic cell count and the incidence of clinical mastitis. J. Dairy Sci. 90:1704-1715.

Oliveira, L., C. Hulland, and P. L. Ruegg. 2013. Characterization of clinical mastitis occurring in cows on 50 large dairy herds in Wisconsin. J. Dairy Sci. 96:7538-7549.

Ott, S. L., and P. R. Novak. 2001. Association of herd productivity and bulk-tank somatic cell counts in US dairy herds in 1996. J. Am. Vet. Med. Assoc. 218:1325-1330.

Pantoja, J. C. F., D. J. Reinemann, and P. L. Ruegg. 2009. Associations among milk quality indicators in raw bulk milk. J. Dairy Sci. 92:4978-4987.

Pinzón-Sánchez, C., and P. L. Ruegg. 2011. Risk factors associated with short-term post- treatment outcomes of clinical mastitis. J Dairy Sci. 94:3397-3410.

Proietto, R. L., L. S. Hinckley, L. K. Fox, and S. M. Andrew. 2013. Evaluation of a clay-based acidic bedding conditioner for dairy cattle bedding. J. Dairy Sci. 96:1044-1053.

Reinemann, D. J. 2011. Troubleshooting high bacteria counts in bulk milk: What needs cleaning, the machine or the cows? Countdown Meet., Melbourne, Australia.

Reinemann, D. J., G. A. Mein, D. R. Bray, D. Reid, and J. S. Britt 1997. Troubleshooting high bacteria counts in farm milk. Pages 16-19 in Natl. Mastitis Counc. Mtg. Proc. Albuquerque, NM. Natl. Mastitis Counc. Inc., Verona, WI.

Rendos, J. J., R. J. Eberhart, and E. M. Kesler. 1975. Microbial populations of teat ends of dairy cows, and bedding materials. J. Dairy Sci. 58:1492-1500.

Rodrigues, A. C. O., D. Z. Caraviello, and P. L. Ruegg. 2005. Management of Wisconsin dairy herds enrolled in milk quality teams. J. Dairy Sci. 88:2660-2671.

Rollin, B. E. 2004. Annual meeting keynote address: Animal agriculture and emerging social ethics for animals. J. Anim. Sci. 82:955964 .

Rowbotham, R. F. 2000 The value of quality milk to the processor. Pages 1-6 in Natl. Mastitis Counc. Mtg. Proc., Cleveland, OH. Natl. Mastitis Counc. Inc., Verona, WI.

Ruegg, P. L., and T. J. Tabone. 2000. The relationship between antibiotic residue violations and somatic cell counts in Wisconsin dairy herds. J. Dairy Sci. 83:2805-2809.

Sapp, S. G., C. Arnot, J. Fallon, T. Fleck, D. Soorholtz, M. SuttonVermeulen, and J. J. H. Wilson. 2009. Consumer trust in the U.S. 
food system: An examination of the recreancy theorem. Rural Sociol. $74: 525-545$.

SAS Institute. 2014. SAS/STAT User's Guide 9.4: Statistics. SAS Institute Inc., Cary, NC.

Schreiner, D. A., and P. L. Ruegg. 2003. Relationship between udder and leg hygiene scores and subclinical mastitis. J. Dairy Sci. 86:3460-3465.

Schukken, Y. H., D. J. Wilson, F. Welcome, L. Garrison-Tikofsky, and R. N. Gonzalez. 2003. Monitoring udder health and milk quality using somatic cell counts. Vet. Res. 34:579-596.

Seegers, H., C. Fourichon, and F. Beaudeau. 2003. Production effects related to mastitis and mastitis economics in dairy cattle herds. Vet. Res. 34:475-491.

Shook, G. E. 1993. Genetic improvement of mastitis through selection on somatic cell count. Vet. Clin. North Am. Food Anim. Pract. 9:563-581.

Tucker, C. B., and D. M. Weary. 2004. Bedding on geotextile mattresses: How much is needed to improve cow comfort? J. Dairy Sci. 87:2889-2895

US Dairy Export Council. 2015. NDM/SMP and whey products pace May exports. Accessed Apr. 14, 2015. www.usdec.org/ Documents/Supplier\%20Site/ResearchandData/USExportData/ SummaryofU.S.ExportsYTD.pdf.

USDA. 2008a. Dairy 2007, Facility Characteristics and Cow Comfort on U.S. Dairy Operations, 2007 USDA-APHIS-VS, CEAH. Fort Collins, CO \#524.1210.

USDA. 2008b. Dairy 2007, Part III: Reference of Dairy Cattle Health and Management Practices in the United States, 2007 USDAAPHIS-VS, CEAH. Fort Collins, CO \#N482.0908.
USDA-AMS. 2015. Federal Order Mailbox Prices, Upper Midwest Milk Marketing Area. Accessed May 13, 2015. http://www.fmma30. com/Homepage/FO30-MailboxPrices.htm.

USDA-NASS. 2014a. Milk Production. ISSN: 1949-1557 Released Feb. 20, 2014. Accessed Mar. 17, 2015. https://usda.mannlib.cornell. edu/MannUsda/viewDocumentInfo.do?documentID=1103.

USDA-NASS. 2014b. Quick Stats Tools. Accessed Apr. 29, 2014 http://www.nass.usda.gov/Quick_Stats/.

US-FDA. 2011. Grade "A" Pasteurized Milk Ordinance, 2011 revision. Accessed Mar. 13, 2014. http://www.fda.gov/downloads/Food/ GuidanceRegulation/UCM291757.pdf

Velthuis, A. G. J., and M. A. P. M. van Asseldonk. 2011. Process audits versus product quality monitoring of bulk milk. J. Dairy Sci. 94:235-249.

Wells, S. J., and S. L. Ott. 1998. What is the quality of the U.S. milk supply? Pages 10-19 in Proc. 37th Annu. Mtg. Natl. Mastitis Counc., St. Louis, MO. Natl. Mastitis Counc., Verona, WI.

Wisconsin Administrative Code. 2013. Chapter ATCP 60 Dairy Farms. Accessed May 13, 2014. http://www.legis.state.wi.us/rsb/ code/atcp/atcp060.pdf.

Wisconsin Department of Administration. 2012. Bureau of Document Services Document Sales \& Distribution, Madison, WI

Zdanowicz, M., J. A. Shelford, C. B. Tucker, D. M. Weary, and M. A. G. von Keyserlingk. 2004. Bacterial populations on teat ends of dairy cows housed in free stalls and bedded with either sand or sawdust. J. Dairy Sci. 87:1694-1701.

Zehner, M. M., R. J. Farnsworth, R. D. Appleman, K. Larntz, and J. A. Springer. 1986. Growth of environmental mastitis pathogens in various bedding materials. J. Dairy Sci. 69:1932-1941. 